\title{
Sensitive sandwich-type electrochemical SARS-CoV-2 nucleocapsid protein immunosensor
}

\author{
Ceren Karaman ${ }^{1} \cdot$ Bahar Bankoğlu Yola ${ }^{2}$ Onur Karaman ${ }^{3} \cdot$ Necip Atar $^{4}$. Illknur Polat ${ }^{5} \cdot$ Mehmet Lütfi Yola $^{5}$ (D)
}

Received: 30 September 2021 / Accepted: 7 November 2021 / Published online: 23 November 2021

(c) The Author(s), under exclusive licence to Springer-Verlag GmbH Austria, part of Springer Nature 2021

\begin{abstract}
A sensitive and fast sandwich-type electrochemical SARS-CoV-2 (COVID-19) nucleocapsid protein immunosensor was prepared based on bismuth tungstate/bismuth sulfide composite $\left(\mathrm{Bi}_{2} \mathrm{WO}_{6} / \mathrm{Bi}_{2} \mathrm{~S}_{3}\right)$ as electrode platform and graphitic carbon nitride sheet decorated with gold nanoparticles (Au NPs) and tungsten trioxide sphere composite $\left(\mathrm{g}_{-} \mathrm{C}_{3} \mathrm{~N}_{4} / \mathrm{Au} / \mathrm{WO}_{3}\right)$ as signal amplification. The electrostatic interactions between capture antibody and $\mathrm{Bi}_{2} \mathrm{WO}_{6} / \mathrm{Bi}_{2} \mathrm{~S}_{3}$ led to immobilization of the capture nucleocapsid antibody. The detection antibody was then conjugated to $g-\mathrm{C}_{3} \mathrm{~N}_{4} / \mathrm{Au} / \mathrm{WO}_{3}$ via the affinity of amino-gold. After physicochemically characterization via transmission electron microscopy (TEM), scanning electron microscopy (SEM), $\mathrm{x}$-ray diffraction (XRD), and x-ray photoelectron spectroscopy (XPS), cyclic voltammetry (CV), differential pulse voltammetry (DPV), and electrochemical impedance spectroscopy (EIS) analysis were implemented to evaluate the electrochemical performance of the prepared immunosensor. The detection of SARS-CoV-2 nucleocapsid protein (SARS-CoV-2 NP) in a small saliva sample $(100.0 \mu \mathrm{L})$ took just $30 \mathrm{~min}$ and yielded a detection limit (LOD) of $3.00 \mathrm{fg} \mathrm{mL}^{-1}$, making it an effective tool for point-of-care COVID-19 testing.
\end{abstract}

Keywords COVID-19 $\cdot \mathrm{g}_{-} \mathrm{C}_{3} \mathrm{~N}_{4} / \mathrm{Au} / \mathrm{WO}_{3} \cdot \mathrm{Bi}_{2} \mathrm{WO}_{6} / \mathrm{Bi}_{2} \mathrm{~S}_{3} \cdot$ Electrochemistry $\cdot$ Voltammetry $\cdot$ Electrochemical impedance spectroscopy $\cdot$ Immunosensor

\section{Introduction}

The recent coronavirus disease (COVID-19), which the World Health Organization (WHO) has proclaimed as a pandemic, has a significant impact on not just health but also the economy [1-3]. Therefore, the WHO urged the international community to conduct widespread diagnostic testing in an effort to fight against the virus spread and reduce the

Mehmet Lütfi Yola

mlutfi.yola@hku.edu.tr

1 Department of Electricity and Energy, Vocational School of Technical Sciences, Akdeniz University, Antalya, Turkey

2 Science and Technology Application and Research Laboratory, Iskenderun Technical University, Hatay, Turkey

3 Department of Medical Imaging Techniques, Vocational School of Health Services, Akdeniz University, Antalya, Turkey

4 Department of Chemical Engineering, Faculty of Engineering, Pamukkale University, Denizli, Turkey

5 Department of Nutrition and Dietetics, Faculty of Health Sciences, Hasan Kalyoncu University, Gaziantep, Turkey number of cases that go undetected [4]. The tools for diagnostic are critical in determining early treatment and isolation decisions for affected people, preventing or halting the spread of infectious diseases. As a consequence, developing a highly-sensitive, precise, and prompt diagnostics tools can be vital in deciding what is best about whether or not to isolate affected individuals, thereby controlling the spread rate of this fatal virus [4-6]. The "gold standard" technique in detecting severe acute respiratory syndrome coronavirus 2 (SARS-CoV-2) that leads COVID-19 can be regarded as the reverse-transcription polymerase chain reaction (RT-PCR) [7]. Although PCR-based tests seem to be specifically tailored for SARS-CoV-2, many variables, including sample variances and viral RNA persistence in the nasal cavity/ throat, impact their accuracy, resulting in false-negative/ false-positive test findings [8-10]. Furthermore, radiological imaging techniques like computed tomography (CT) are considered to be one of the most effective ways to detect the COVID-19. However, owing to some constraints such as being available only at health facilities, difficulties in accessibility, and high cost, it is unlikely to be utilized for swift and large-scale testing $[11,12]$. Therefore, the development 
of time-saving, extremely sensitive, and precise, cost-effective COVID-19 electroanalytical sensing technologies is essential and would have a substantial impact on the control of the pandemic [13].

There has recently been a drive to fabricate COVID-19 serological assays that identify immunological or viral proteins in the blood sample of infected people. Since proteins are homogenously distributed in the blood, serological specimens are more persistent than viral RNA and have fewer variations than nasopharyngeal or oropharyngeal viral RNA specimens, reducing the risk of false-negative test findings [14]. In a few publications, it has been established that lateral flow immunoassay (LFA) methods incorporating colorimetry/fluorescence approaches for targeting the $\operatorname{IgG}, \operatorname{IgM}$, or IgA immunoglobulins generated as a reaction to SARSCoV-2 during the early stages of infection may accurately diagnose viral RNA [8, 15-21]. Moreover, the serological assays will aid in assessing a population's immunological response to spontaneous infection as well as vaccination [7]. Despite the fact that these devices are user-friendly and swift, they generally have low sensitivity and need at least two antibodies to detect. Therefore, electrochemical monitoring of SARS-CoV-2 antibodies has emerged as a viable approach to solve these limitations [7]. This technique has a high ability to distinguish tiny differences on the electrode surface from the recognition case, thereby allowing labelfree detection without any need for a single antibody. Electrochemical immunosensors have significant features that are appropriate for today's needs, such as simplicity of use, cost and time effectiveness, portability, swiftness, and high sensitivity [13]. Previously, various electrochemical biosensors were employed to detect viral antigens from a variety of fatal viruses, including Hepatitis, Dengue, Rabies, and Zika [22-24]. Moreover, due to the current COVID-19 pandemic, biosensor research aimed at identifying and quantifying SARS-CoV-2 has emerged. However, interfacial contamination caused by biomolecule adsorption is one of the most serious challenges with electrochemical sensing technologies, limiting their practical applicability [25]. Therefore, the fabrication of an effictice immunosensor surface modified with suitable nanomaterials, which restricts non-specific adsorption of molecules without interacting with particular analyte detection, is one plausible option to this challenge.

Semiconductor nanocrystals were used for various applications such as energy [26], supercapacitor electrode material [27, 28], and catalysis [29]. Especially, bismuthbased semiconductors having specific morphology show desirable sensor catalytic performance [30, 31]. Among these semiconductors, bismuth sulfide $\left(\mathrm{Bi}_{2} \mathrm{~S}_{3}\right)$ belonging a tunable band gap (from 1.2 to $1.8 \mathrm{eV}$ ) demonstrates good stability, non-toxicity, and conductivity, providing superior electronic properties for sensor/biosensor applications. Nonetheless, owing to the easy photogenerated carrier recombination, its practical applications are limited. In order to eliminate this carrier recombination problem, the several methods such as the element dopping and the preparation of heterostructures can be utilized for improvement of catalytic activity. The layered $\mathrm{Bi}_{2} \mathrm{WO}_{6}$ has received a great deal of interest thanks to its stability and superior catalytic properties [32]. Its layered structure composes of the octahedral $\left(\mathrm{WO}_{4}\right)^{2-}$ sheets and bismuth oxide $\left(\mathrm{Bi}_{2} \mathrm{O}_{2}\right)^{2+}$ layers, indicating easy charge transfer. This structure was formed by an intergrowth of $\mathrm{WO}_{4}{ }^{2-}$ ions between $\left(\mathrm{Bi}_{2} \mathrm{O}_{2}\right)^{2+}$ layers [33]. Due to internal electric field, the recombination of charge carriers is reduced and sensor/biosensor's catalytic activity increases. In addition, its application areas can be expanded by dopping treatment [34] and the heterojunction construction [35]. In these methods, the coupling with two different semiconductor into heterojunctions is effective approach [36]. Thus, we prepared $\mathrm{Bi}_{2} \mathrm{WO}_{6} / \mathrm{Bi}_{2} \mathrm{~S}_{3}$ as electrode platform in this study.

The preparation of $\mathrm{g}-\mathrm{C}_{3} \mathrm{~N}_{4}$ can be carried out by thermal pyrolysis of nitrogen-rich precursors such as melamine and urea [37]. Due to its excellent stability, low toxicity and conductivity, it has been utilized in electrochemical applications [38]. $g-\mathrm{C}_{3} \mathrm{~N}_{4}$ with band gap of $2.7 \mathrm{eV}$ and $\mathrm{WO}_{3}$ with band gap of $2.8 \mathrm{eV}$ can be made up of a $\mathrm{Z}$-scheme heterojunction [39], providing the prevention of the electron-hole recombination. In addition, tungsten trioxide $\left(\mathrm{WO}_{3}\right)$ has superior electronic and chemical properties and biocompatibility [40]. A mediator such as AuNPs is generally needed for facilitating the electron transfer in Z-scheme heterojunction. Due to AuNPs' electrical conductivity and large specific surface area, the immobilization of antibodies also becomes easier [41]. Hence, g- $\mathrm{C}_{3} \mathrm{~N}_{4} / \mathrm{Au} / \mathrm{WO}_{3}$ as signal amplification can separate electron-hole, providing the sensitivity of sensor performance.

Herein, in the light of all aforementioned points in mind, it was aimed to fabricate a novel electrochemical SARS-CoV-2 nucleocapsid protein immunosensor based on $\mathrm{Bi}_{2} \mathrm{WO}_{6} / \mathrm{Bi}_{2} \mathrm{~S}_{3}$ and $\mathrm{g}-\mathrm{C}_{3} \mathrm{~N}_{4} / \mathrm{Au} / \mathrm{WO}_{3}$ for COVID-19 detection for the first time in literature. The fabricated immunosensor provides a number of benefits, including ease of use, speed, and selectivity. Moreover, a precise LOD of $3.00 \mathrm{fg} \mathrm{mL}^{-1}$ was acquired with high selectivity and no interference in saliva samples. Hence, the fabricated electrochemical SARS-CoV-2 nucleocapsid protein immunosensor presents a new perspective in the point-ofcare COVID-19 testing. 


\section{Experimental section}

\section{Materials}

SARS-CoV-2 NP, capture human monoclonal anti-SARSCoV-2 nucleocapsid antibody (c-SARS-CoV-2-Ab ${ }_{1}$ ), detection monoclonal anti-SARS-CoV-2 nucleocapsid antibody (d-SARS-CoV-2-Ab ${ }_{2}$ ), MERS-CoV nucleocapsid protein (MERS-CoV NP), coronavirus nucleoprotein (SARS-CoV NP), influenza A antigen (H1N1), $\mathrm{Bi}\left(\mathrm{NO}_{3}\right)_{3} \cdot 5 \mathrm{H}_{2} \mathrm{O}, \mathrm{Na}_{2} \mathrm{~S} \cdot 9 \mathrm{H}_{2} \mathrm{O}$, carbamide, $\mathrm{Na}_{2} \mathrm{WO}_{4} \cdot 2 \mathrm{H}_{2} \mathrm{O}$, melamine, sodium borohydride $\left(\mathrm{NaBH}_{4}\right)$, and chloroauric acid $\left(\mathrm{HAuCl}_{4}\right)$ were supplied from Sigma-Aldrich. Moreover, during the experiments, $0.1 \mathrm{~mol} . \mathrm{L}^{-1}$ phosphate-buffered saline (PBS) solution with a $\mathrm{pH}$ value of 7.0 was employed as a supporting electrolyte and diluting buffer solution.

\section{Apparatus for evaluation of nanomaterials}

Surface morphological characteristics were explored by using a SEM (ZEISS EVO 50) SEM and a TEM (JEOL 2100). X-ray spectrum of nanostructrues was collected by a Rigaku X-ray diffractometer with $\mathrm{Cu}-\mathrm{K}$ radiation $(\lambda=0.150 \mathrm{~nm})$. The PHI 5000 Versa Probe spectrometer was used to perform the XPS survey. UV-Vis and Raman measurements were performed by Mettler Toledo and LabRam HR Raman Spectrometer, respectively. Electrochemical characterization techniques such as cyclic voltammetry, differential pulse voltammetry, and electrochemical empdance spectroscopy were also conducted via the Gamry Reference 600 workstation (Gamry, USA).

\section{Preparation of $\mathrm{Bi}_{2} \mathrm{WO}_{6}, \mathrm{Bi}_{2} \mathrm{~S}_{3}$, and $\mathrm{Bi}_{2} \mathrm{WO}_{6} / \mathrm{Bi}_{2} \mathrm{~S}_{3}$}

For preparation of $\mathrm{Bi}_{2} \mathrm{~S}_{3}$ nanorods, the addition of $\mathrm{Bi}\left(\mathrm{NO}_{3}\right)_{3} \cdot 5 \mathrm{H}_{2} \mathrm{O}(1.90 \mathrm{~g})$ into ethanol solution $(30.0 \mathrm{~mL})$ was firstly performed and stirred during $30 \mathrm{~min}$. Then, $\mathrm{Na}_{2} \mathrm{~S} \cdot 9 \mathrm{H}_{2} \mathrm{O}$ aqueous solution $\left(0.1 \mathrm{~g} \mathrm{~mL}^{-1}\right)$ was prepared, stirred during $45 \mathrm{~min}$ and slowly added into $\mathrm{Bi}\left(\mathrm{NO}_{3}\right)_{3} \cdot 5 \mathrm{H}_{2} \mathrm{O}$ solution, providing the black suspension. After that, carbamide solution $\left(0.1 \mathrm{~g} \mathrm{~mL}^{-1}\right)$ was transferred into the above solution and the suspension was subjected to $200{ }^{\circ} \mathrm{C}$ for $20 \mathrm{~h}$ in a Teflon steel autoclave. $\mathrm{Bi}_{2} \mathrm{~S}_{3}$ nanorods were filtered, washed, and dried at $25.0^{\circ} \mathrm{C}$.

For preparation of $\mathrm{Bi}_{2} \mathrm{WO}_{6}$, the mixture of $\mathrm{Na}_{2} \mathrm{WO}_{4} \cdot 2 \mathrm{H}_{2} \mathrm{O}$ $(3.0 \mathrm{mmol}, 10.0 \mathrm{~mL})$ and $\mathrm{Bi}\left(\mathrm{NO}_{3}\right)_{3} \cdot 5 \mathrm{H}_{2} \mathrm{O}(3.0 \mathrm{mmol}$, $10.0 \mathrm{~mL}$ ) was prepared and strongly stirred during $20 \mathrm{~min}$. Then, the mixture was subjected to $200{ }^{\circ} \mathrm{C}$ for $15 \mathrm{~h}$ in a Teflon steel autoclave. The resulting product as $\mathrm{Bi}_{2} \mathrm{WO}_{6}$ was filtered, washed, and dried at $60.0^{\circ} \mathrm{C}$.
To prepare $\mathrm{Bi}_{2} \mathrm{WO}_{6} / \mathrm{Bi}_{2} \mathrm{~S}_{3}$ composite, $\mathrm{Bi}_{2} \mathrm{~S}_{3}$ nanorods (10.0 mmol) and $\mathrm{Bi}_{2} \mathrm{WO}_{6}(10.0 \mathrm{mmol})$ were mixed at $1: 1$, $\mathrm{v} / \mathrm{v}$ for $40 \mathrm{~min}$. After that, $\mathrm{Bi}_{2} \mathrm{WO}_{6} / \mathrm{Bi}_{2} \mathrm{~S}_{3}$ composite having heterojunction was collected, filtered, and dried at $40{ }^{\circ} \mathrm{C}$.

\section{$\mathrm{Bi}_{2} \mathrm{WO}_{6} / \mathrm{Bi}_{2} \mathrm{~S}_{3}$ modified GCE $\left(\mathrm{Bi}_{2} \mathrm{WO}_{6} / \mathrm{Bi}_{2} \mathrm{~S}_{3} /\right.$ $\mathrm{GCE}$ ) as electrochemical sensor platform with c-SARS-CoV-2-Ab 1 and SARS-CoV-2 NP immobilizations}

The glassy carbon electrode (GCE) was prepared as follows to be utilized in the further steps [42]: firstly, $0.1 \mu \mathrm{m}$ and $0.05 \mu \mathrm{m}$ alumina slurries were transferred on cleaning pads, respectively. Then, the GCE was polished with these alumina slurries for $20 \mathrm{~min}$. Subsequently, the electrodes were rinsed with isopropyl alcohol and acetonitrile, respectively to remove the alumina remains at $25^{\circ} \mathrm{C}$. The electrode modifications with $\mathrm{Bi}_{2} \mathrm{WO}_{6}, \mathrm{Bi}_{2} \mathrm{~S}_{3}$, and $\mathrm{Bi}_{2} \mathrm{WO}_{6}$ / $\mathrm{Bi}_{2} \mathrm{~S}_{3}$ suspensions $\left(10.0 \mu \mathrm{L}, 0.1 \mathrm{mg} \mathrm{mL}^{-1}\right)$ were performed by dropping these suspensions on the clean GCEs. After $20 \mathrm{~min}$, the solvent removal was carried out by infrared heat lamp, providing $\mathrm{Bi}_{2} \mathrm{WO}_{6}, \mathrm{Bi}_{2} \mathrm{~S}_{3}$, and $\mathrm{Bi}_{2} \mathrm{WO}_{6} / \mathrm{Bi}_{2} \mathrm{~S}_{3}$ modified GCEs $\left(\mathrm{Bi}_{2} \mathrm{WO}_{6} / \mathrm{GCE}, \mathrm{Bi}_{2} \mathrm{~S}_{3} / \mathrm{GCE}\right.$, and $\mathrm{Bi}_{2} \mathrm{WO}_{6} / \mathrm{Bi}_{2} \mathrm{~S}_{3} /$ $\mathrm{GCE})$. The c-SARS-CoV-2- $\mathrm{Ab}_{1}$ immobilization on $\mathrm{Bi}_{2} \mathrm{WO}_{6} /$ $\mathrm{Bi}_{2} \mathrm{~S}_{3} / \mathrm{GCE}$ was performed by dropping of $20 \mu \mathrm{L}$ c-SARS$\mathrm{CoV}-2-\mathrm{Ab}_{1}$ dispersion (with a concentration of $20.0 \mu \mathrm{g}$. $\mathrm{mL}^{-1}$ ) on $\mathrm{Bi}_{2} \mathrm{WO}_{6} / \mathrm{Bi}_{2} \mathrm{~S}_{3} / \mathrm{GCE}$ via strong electrostatic interactions between amino group of c-SARS-CoV-2-Ab ${ }_{1}$ and bismuth oxide $\left(\mathrm{Bi}_{2} \mathrm{O}_{2}\right)^{2+}$. The electrodes were maintained at $37.0{ }^{\circ} \mathrm{C}$ for $15 \mathrm{~min}$ (c-SARS-CoV-2- $\mathrm{Ab}_{1} / \mathrm{Bi}_{2} \mathrm{WO}_{6} / \mathrm{Bi}_{2} \mathrm{~S}_{3} /$ GCE). Then, BSA $(3.0 \% \mathrm{w} / \mathrm{v})$ was incubated on c-SARS$\mathrm{CoV}-2-\mathrm{Ab}_{1} / \mathrm{Bi}_{2} \mathrm{WO}_{6} / \mathrm{Bi}_{2} \mathrm{~S}_{3} / \mathrm{GCE}$ at $37.0{ }^{\circ} \mathrm{C}$ over $15 \mathrm{~min}$ to eliminate the non-specific interactions (BSA/c-SARS-CoV$\left.2-\mathrm{Ab}_{1} / \mathrm{Bi}_{2} \mathrm{WO}_{6} / \mathrm{Bi}_{2} \mathrm{~S}_{3} / \mathrm{GCE}\right)$. Each of SARS-CoV-2 NP with different concentrations was incubated to BSA/c-SARS$\mathrm{CoV}-2-\mathrm{Ab}_{1} / \mathrm{Bi}_{2} \mathrm{WO}_{6} / \mathrm{Bi}_{2} \mathrm{~S}_{3} / \mathrm{GCE}$ for $15 \mathrm{~min}$ at $37.0^{\circ} \mathrm{C}$ via specific protein-antibody interactions (SARS-CoV-2 NP/ $\left.\mathrm{BSA} / \mathrm{c}-\mathrm{SARS}-\mathrm{CoV}-2-\mathrm{Ab}_{1} / \mathrm{Bi}_{2} \mathrm{WO}_{6} / \mathrm{Bi}_{2} \mathrm{~S}_{3} / \mathrm{GCE}\right)$. Lastly, the whole electrode including SARS-CoV-2 NP and c-SARS$\mathrm{CoV}-2-\mathrm{Ab}_{1}$ was interacted with $0.1 \mathrm{M}$ PBS (pH 7.0) to take away non-interacting SARS-CoV-2 nucleocapsid proteins.

\section{Preparation of $\mathrm{g}-\mathrm{C}_{3} \mathrm{~N}_{4}, \mathrm{~g}-\mathrm{C}_{3} \mathrm{~N}_{4} / \mathrm{WO}_{3}$, and g- $\mathrm{C}_{3} \mathrm{~N}_{4} / \mathrm{Au} /$ $\mathrm{WO}_{3}$}

Firstly, $\mathrm{g}^{-} \mathrm{C}_{3} \mathrm{~N}_{4}$ preparation was performed [43]. For this aim, the calcination of melamine $(20.0 \mathrm{~g})$ was conducted at $500{ }^{\circ} \mathrm{C}$ over $90 \mathrm{~min}$. After the cooling treatment at $25^{\circ} \mathrm{C}$, the obtained yellow product was transferred into the combustion boat and the calcination treatment was performed at $480{ }^{\circ} \mathrm{C}$ for $120 \mathrm{~min}$ and after cooling, the white $\mathrm{g}-\mathrm{C}_{3} \mathrm{~N}_{4}$ was obtained. 
For $\mathrm{g}^{-} \mathrm{C}_{3} \mathrm{~N}_{4} / \mathrm{WO}_{3}$ preparation [44], the mixture of $\mathrm{g}-\mathrm{C}_{3} \mathrm{~N}_{4}$ $(0.25 \mathrm{~g}), \mathrm{Na}_{2} \mathrm{WO}_{4} \cdot 2 \mathrm{H}_{2} \mathrm{O}(1.00 \mathrm{~g})$, and ethanol $(150.0 \mathrm{~mL})$ was prepared under strong stirring. Afterward, the concentrated $\mathrm{HCl}(10.0 \mathrm{~mL})$ was gently added into this mixture and the dispersion was calcined at $420^{\circ} \mathrm{C}$ for $120 \mathrm{~min}$, providing g- $\mathrm{C}_{3} \mathrm{~N}_{4} / \mathrm{WO}_{3}$ composite.

For $\mathrm{g}-\mathrm{C}_{3} \mathrm{~N}_{4} / \mathrm{Au} / \mathrm{WO}_{3}$ preparation, the mixture of $\mathrm{g}-\mathrm{C}_{3} \mathrm{~N}_{4} /$ $\mathrm{WO}_{3}(150.0 \mathrm{mg}), \mathrm{HAuCl}_{4}(50.0 \mu \mathrm{L}, 20.0 \mathrm{mM})$, and ultrapure water $(50.0 \mathrm{~mL})$ was prepared. After that, $\mathrm{NaBH}_{4}$ $(2.0 \mathrm{~mL}, 20.0 \mathrm{mM})$ was added into this dispersion under strong stirring and $\mathrm{g}-\mathrm{C}_{3} \mathrm{~N}_{4} / \mathrm{Au} / \mathrm{WO}_{3}$ was dried at $25^{\circ} \mathrm{C}$.

\section{g- $\mathrm{C}_{3} \mathrm{~N}_{4} / \mathrm{Au} / \mathrm{WO}_{3}$ signal amplification with d-SARS-CoV-2-Ab ${ }_{2}$ conjugation}

d-SARS-CoV-2- $\mathrm{Ab}_{2}$ conjugation was performed by addition of detection antibody $\left(20.0 \mu \mathrm{L}, 20.0 \mu \mathrm{g} \mathrm{mL}^{-1}\right)$ into g- $\mathrm{C}_{3} \mathrm{~N}_{4} /$ $\mathrm{Au} / \mathrm{WO}_{3}\left(20.0 \mu \mathrm{L}, 20.0 \mathrm{mg} \mathrm{mL}{ }^{-1}\right)$ signal amplification via strong amino-gold affinity [45, 46]. After the vigorous stirring at $37.0^{\circ} \mathrm{C}$ for $30 \mathrm{~min}$, d-SARS-CoV-2- $\mathrm{Ab}_{2} / \mathrm{g}_{-} \mathrm{C}_{3} \mathrm{~N}_{4} / \mathrm{Au} /$ $\mathrm{WO}_{3}$ was centrifugated at $5000 \mathrm{rpm}$ for $30 \mathrm{~min}$.

\section{Electrochemical characterizations}

The resulting SARS-CoV-2 nucleocapsid protein immunosensor was constructed by antibody-nucleocapsid protein interactions between d-SARS-CoV-2- $\mathrm{Ab}_{2} / \mathrm{g}-\mathrm{C}_{3} \mathrm{~N}_{4} /$ $\mathrm{Au} / \mathrm{WO}_{3}$ and SARS-CoV-2 NP/BSA/c-SARS-CoV-2-Ab 1 $\mathrm{Bi}_{2} \mathrm{WO}_{6} / \mathrm{Bi}_{2} \mathrm{~S}_{3} / \mathrm{GCE}$. By drop-casting method, $20.0 \mu \mathrm{L}$ d-SARS-CoV-2- $\mathrm{Ab}_{2} / \mathrm{g}-\mathrm{C}_{3} \mathrm{~N}_{4} / \mathrm{Au} / \mathrm{WO}_{3}$ dispersion (with a concentration of $20.0 \mathrm{mg} \mathrm{mL}^{-1}$ ) was coated on electrode surface such as SARS-CoV-2 NP/BSA/c-SARS-CoV-2-Ab 1 $\mathrm{Bi}_{2} \mathrm{WO}_{6} / \mathrm{Bi}_{2} \mathrm{~S}_{3} / \mathrm{GCE}$, at a $30 \mathrm{~min}$ immunological response time. The final electrochemical immunosensor was tagged as g- $\mathrm{C}_{3} \mathrm{~N}_{4} / \mathrm{Au} / \mathrm{WO}_{3} / \mathrm{d}-\mathrm{SARS}-\mathrm{CoV}-2-\mathrm{Ab}_{2} / \mathrm{SARS}-\mathrm{CoV}-2 \mathrm{NP} /$ $\mathrm{BSA} / \mathrm{c}-\mathrm{SARS}-\mathrm{CoV}-2-\mathrm{Ab}_{1} / \mathrm{Bi}_{2} \mathrm{WO}_{6} / \mathrm{Bi}_{2} \mathrm{~S}_{3} / \mathrm{GCE}$ and this electrochemical immunosensor was stored in $0.1 \mathrm{M}$ PBS $(\mathrm{pH}$ $7.0,3.0 \mathrm{~mL}$ ) without pressure fluctuations at $25^{\circ} \mathrm{C}$. The electrochemical performance of the SARS-CoV-2 nucleocapsid protein immunosensor was monitored in $0.1 \mathrm{M}$ PBS (pH 7.0, $2.0 \mathrm{~mL}$ ) containing $1.0 \mathrm{mM} \mathrm{H}_{2} \mathrm{O}_{2}$ solution in the range of $+0.0 /+0.4 \mathrm{~V}$. Scheme 1 shows the preparation procedure of electrochemical SARS-CoV-2 immunosensor including the preparations of electrode platform and signal amplification.

\section{Processing of samples}

The saliva samples were acquired from five healthy individuals (See S. M. for a further description of sample processing).

\section{Results and discussion}

\section{Fundamental of electrochemical SARS-CoV-2 NP immunosensor based on $\mathrm{Bi}_{2} \mathrm{WO}_{6} / \mathrm{Bi}_{2} \mathrm{~S}_{3}$ and $\mathrm{g}-\mathrm{C}_{3} \mathrm{~N}_{4} /$ $\mathrm{Au} / \mathrm{WO}_{3}$}

$\mathrm{Bi}_{2} \mathrm{WO}_{6} / \mathrm{Bi}_{2} \mathrm{~S}_{3}$ was employed as a sensor platform in immunosensor fabrication. $\mathrm{Bi}_{2} \mathrm{WO}_{6}$ with a layered structure comprises $\mathrm{WO}_{4}{ }^{2-}$ ions' intergrowth between $\left(\mathrm{Bi}_{2} \mathrm{O}_{2}\right)^{2+}$ layers. Due to the layered structure, $\mathrm{Bi} 6 \mathrm{~s}$ and $\mathrm{O} 2 \mathrm{p}$ levels create the dispersed valence band, providing the catalytic effect [47]. In addition, $\mathrm{Bi}_{2} \mathrm{WO}_{6}$ has important function as a framework to prepare $\mathrm{Bi}_{2} \mathrm{WO}_{6} / \mathrm{Bi}_{2} \mathrm{~S}_{3}$ composite. Sodium sulfide as sulfur source can release $\mathrm{S}^{2-}$ ion to react with $\mathrm{Bi}_{2} \mathrm{WO}_{6}$ via ion change, providing $\mathrm{Bi}_{2} \mathrm{~S}_{3}$ nanorods' dispersion [33]. In immunosensor construction, the efficient electrostatic interactions between amino group of c-SARS$\mathrm{CoV}-2-\mathrm{Ab}_{1}$ and $\mathrm{Bi}_{2} \mathrm{WO}_{6} / \mathrm{Bi}_{2} \mathrm{~S}_{3}$ composite also provided the strong capture antibody immobilization on electrode surface.

g- $\mathrm{C}_{3} \mathrm{~N}_{4} / \mathrm{Au} / \mathrm{WO}_{3}$ composite was used as a signal amplification for electrochemical SARS-CoV-2 NP immunosensor. This composite composed a Z-scheme heterojunction [39], resulting in the decrease of the electron transfer. Hence, a mediator, which facilitated electron transfer, is necessary at the interface of heterojunction. AuNPs can be a candidate intermediate owing to their large specific surface area, the ability of the charge separation promotion, and the antibody's easy immobilization [48]. Hence, $\mathrm{g}-\mathrm{C}_{3} \mathrm{~N}_{4} / \mathrm{Au} / \mathrm{WO}_{3}$ composite both integrates substantial benefits and efficiently facilitates electron transport, thereby resulting in the development of a sensitive immunosensor.

Finally, $\mathrm{H}_{2} \mathrm{O}_{2}$ was utilized as a redox probe in this work due to its easy oxidation into $\mathrm{O}_{2}$ and continuous monitoring. The related electrochemical reaction mechanism for $\mathrm{H}_{2} \mathrm{O}_{2}$ in potential range was also provided on Scheme 1 as $\mathrm{H}_{2} \mathrm{O}_{2} \leftrightarrow \mathrm{O}_{2}+2 \mathrm{H}^{+}+2 \mathrm{e}^{-}[49,50]$.

\section{Characterizations of $\mathrm{Bi}_{2} \mathrm{WO}_{6}, \mathrm{Bi}_{2} \mathrm{~S}_{3}$, and $\mathrm{Bi}_{2} \mathrm{WO}_{6} / \mathrm{Bi}_{2} \mathrm{~S}_{3}$}

The morphological features of $\mathrm{Bi}_{2} \mathrm{WO}_{6}, \mathrm{Bi}_{2} \mathrm{~S}_{3}$, and $\mathrm{Bi}_{2} \mathrm{WO}_{6} / \mathrm{Bi}_{2} \mathrm{~S}_{3}$ composite were investigated on Fig. 1 . The nanoflower and ultrathin nanosheet morphological structure of $\mathrm{Bi}_{2} \mathrm{WO}_{6}$ with about $2.5 \mu \mathrm{m}$ diameter and 490-510 nm length were shown on Fig. 1A. Figure 1B shows pure $\mathrm{Bi}_{2} \mathrm{~S}_{3}$ having a nanorod structure with width of 35-45 nm. In addition, the deposition of $\mathrm{Bi}_{2} \mathrm{~S}_{3}$ nanorods with $120-140 \mathrm{~nm}$ lengths on $\mathrm{Bi}_{2} \mathrm{WO}_{6}$ nanoflower was shown on Fig. 1C. Finally, the elemental mapping of composite material (Fig. 1D) confirmed $\mathrm{Bi}_{2} \mathrm{WO}_{6} / \mathrm{Bi}_{2} \mathrm{~S}_{3}$ 

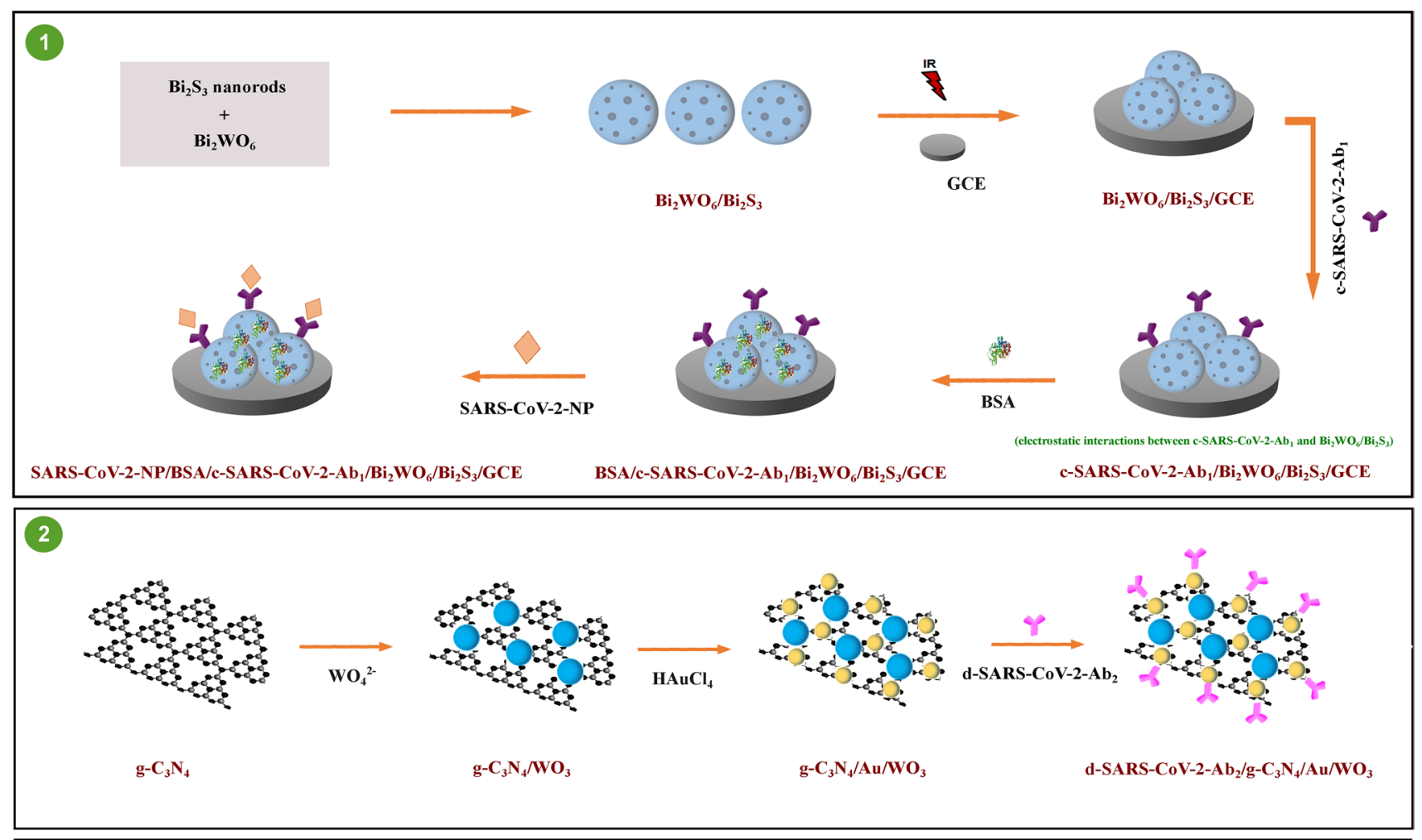

3

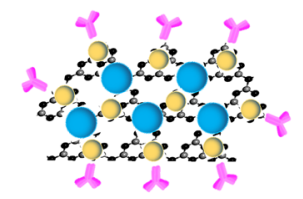

d-SARS-CoV-2-Ab $/ \mathrm{g}_{2}-\mathrm{C}_{3} \mathrm{~N}_{4} / \mathrm{Au} / \mathrm{WO}_{3}$

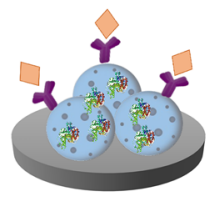

SARS-CoV-2-NP/BSA/c-SARS-CoV-2-Ab ${ }_{1} / \mathrm{Bi}_{2} \mathrm{WO}_{6} / \mathrm{Bi}_{2} \mathrm{~S}_{3} / \mathrm{GCE}$

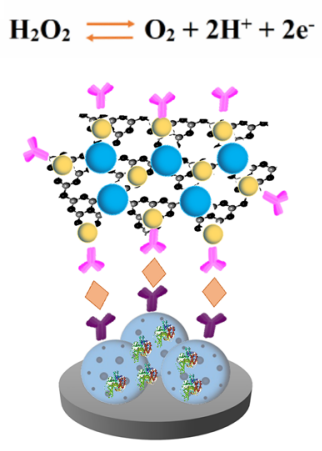

Electrochemical SARS-CoV-2-NP immunosensor

Scheme 1 Schematic illustration of the fabrication procedure of electrochemical SARS-CoV-2 immunosensor

formation in presence of $\mathrm{Bi}, \mathrm{W}$, and S. Secondly, XPS analysis was carried out to show the analysis patterns of $\mathrm{Bi}_{2} \mathrm{WO}_{6}, \mathrm{Bi}_{2} \mathrm{~S}_{3}$, and $\mathrm{Bi}_{2} \mathrm{WO}_{6} / \mathrm{Bi}_{2} \mathrm{~S}_{3}$ (Fig.S1AS1 ). According to Fig. S1A, Bi 4f7/2 peaks at 157.8 and $163.7 \mathrm{eV}$, Bi $4 \mathrm{f} 5 / 2$ peaks at 158.8 and $164.1 \mathrm{eV}$, and $\mathrm{S} 2 \mathrm{p} 3 / 2$ peak at $161.2 \mathrm{eV}$ verified the presence of $\mathrm{Bi}^{3+}$ and $\mathrm{S}^{2-}$, respectively. In addition, the peaks at 34.9 and $37.3 \mathrm{eV}$ were ascribed to $\mathrm{W} 4 \mathrm{f} 7 / 2$ and $\mathrm{W} 4 \mathrm{f} 5 / 2$, respectively. Then, XRD patterns of $\mathrm{Bi}_{2} \mathrm{WO}_{6}, \mathrm{Bi}_{2} \mathrm{~S}_{3}$, and $\mathrm{Bi}_{2} \mathrm{WO}_{6} / \mathrm{Bi}_{2} \mathrm{~S}_{3}$ were demonstrated on Fig. S1B. The characteristic XRD peaks belonging to $\mathrm{Bi}_{2} \mathrm{WO}_{6}$ and $\mathrm{Bi}_{2} \mathrm{~S}_{3}$ were attributed to the orthorhombic phases of $\mathrm{Bi}_{2} \mathrm{~S}_{3}$ and $\mathrm{Bi}_{2} \mathrm{WO}_{6}[51,52]$. The same XRD peaks on the patterns of $\mathrm{Bi}_{2} \mathrm{WO}_{6}$ and $\mathrm{Bi}_{2} \mathrm{~S}_{3}$ were observed on XRD pattern of $\mathrm{Bi}_{2} \mathrm{WO}_{6} / \mathrm{Bi}_{2} \mathrm{~S}_{3}$ and it is concluded that $\mathrm{Bi}_{2} \mathrm{WO}_{6} / \mathrm{Bi}_{2} \mathrm{~S}_{3}$ was prepared with a high purity.

According to Raman spectra (Fig. 2A), the obvious peaks such as the symmetric and asymmetric stretching peaks between $\mathrm{W}$ and $\mathrm{O}$ atoms on $\mathrm{Bi}_{2} \mathrm{WO}_{6}$ in $600-1000 \mathrm{~cm}^{-1}$ region were observed. Moreover, the band observed at $308 \mathrm{~cm}^{-1}$ was corresponded to O-WO- group's bending, whereas the bands detected 
Fig. 1 SEM images of $\mathbf{A}$ $\mathrm{Bi}_{2} \mathrm{WO}_{6}, \mathbf{B} \mathrm{Bi}_{2} \mathrm{~S}_{3}$, and $\mathbf{C}$ $\mathrm{Bi}_{2} \mathrm{WO}_{6} / \mathrm{Bi}_{2} \mathrm{~S}_{3}$; D elemental mapping of $\mathrm{Bi}_{2} \mathrm{WO}_{6} / \mathrm{Bi}_{2} \mathrm{~S}_{3}$ composite
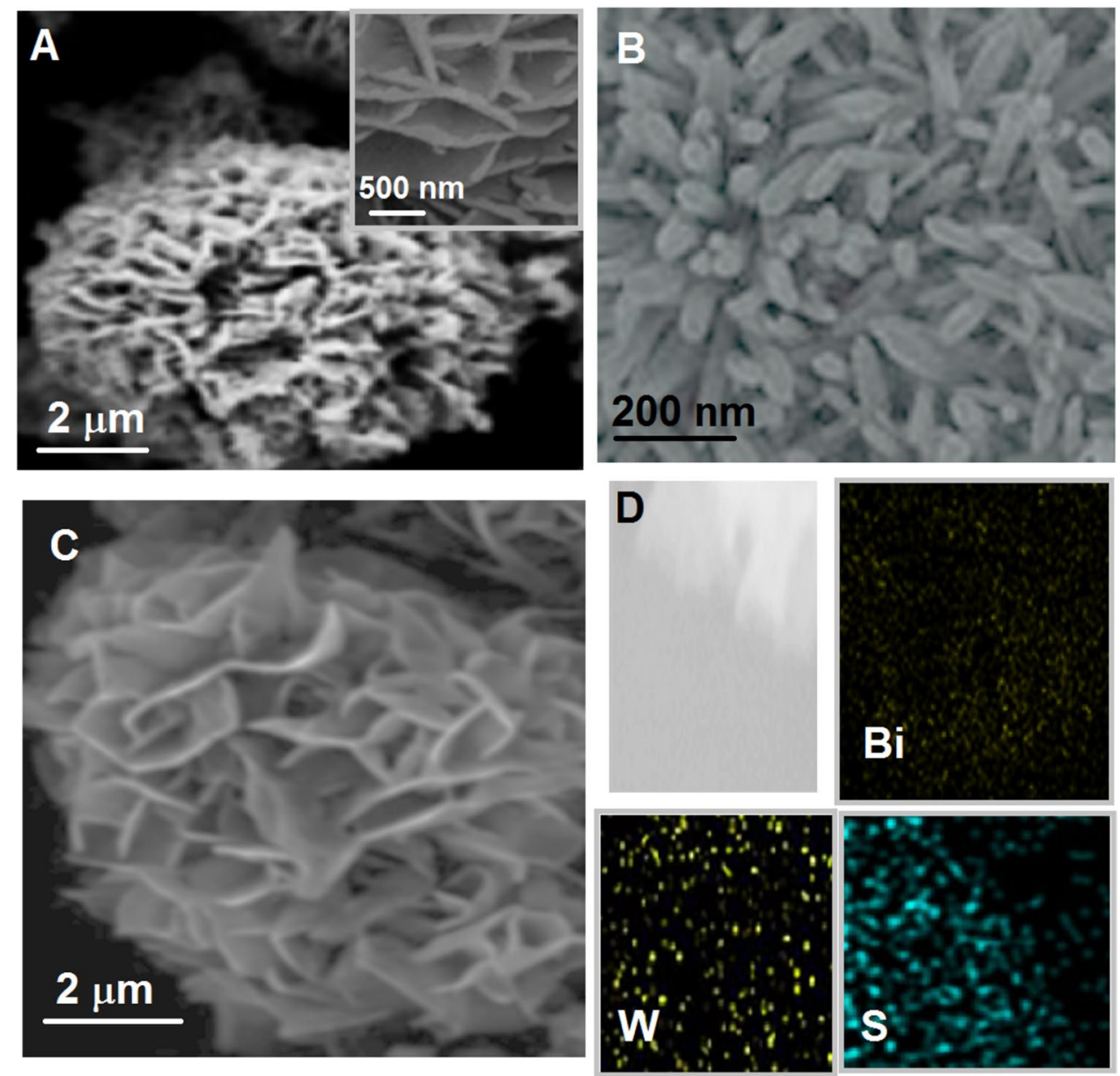

Fig. 2 Raman (A) and $\mathbf{B}$ UVVis spectra of $\mathrm{Bi}_{2} \mathrm{WO}_{6}, \mathrm{Bi}_{2} \mathrm{~S}_{3}$, and $\mathrm{Bi}_{2} \mathrm{WO}_{6} / \mathrm{Bi}_{2} \mathrm{~S}_{3}$
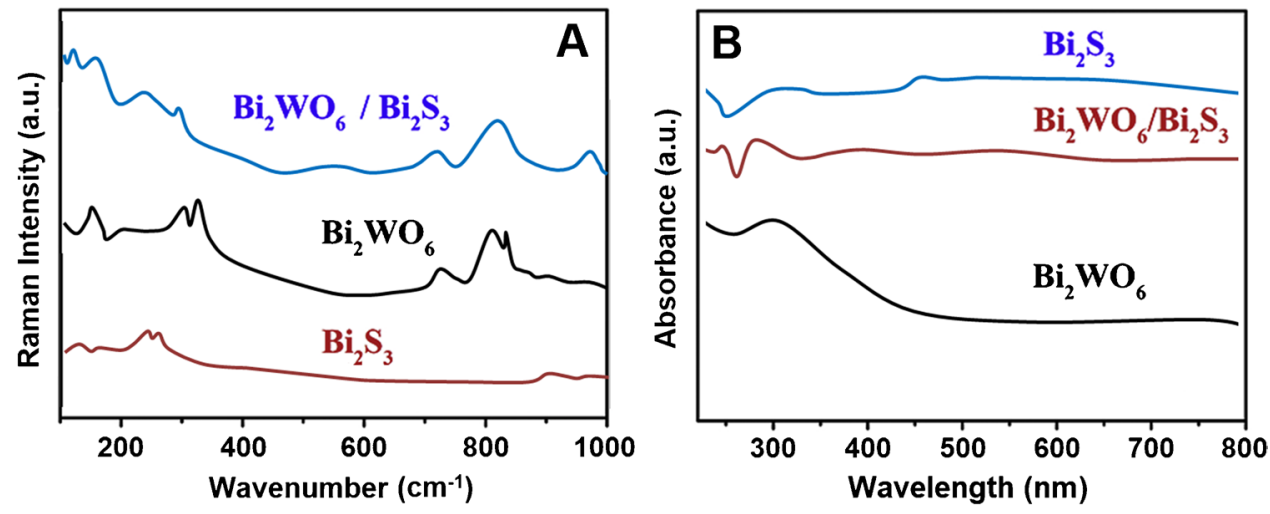

at 788 and $822 \mathrm{~cm}^{-1}$ were ascribed to asymmetrical and symmetrical modes of O-WO groups, respectively [53, 54]. The asymmetrical bridging mode relating to the tungstate chain was confirmed by the peak at $698 \mathrm{~cm}^{-1}$. On Raman spectra of $\mathrm{Bi}_{2} \mathrm{WO}_{6} / \mathrm{Bi}_{2} \mathrm{~S}_{3}$, the novel peaks at 101 and $229 \mathrm{~cm}^{-1}$ and the increased peak intensity at $254 \mathrm{~cm}^{-1}$ confirmed the presence of $\mathrm{Bi}_{2} \mathrm{~S}_{3}$ on composite [55]. In addition, the specific bands attributing to $\mathrm{Bi}_{2} \mathrm{WO}_{6}$ were observed on Raman spectra of $\mathrm{Bi}_{2} \mathrm{WO}_{6} / \mathrm{Bi}_{2} \mathrm{~S}_{3}$. Figure $2 \mathrm{~B}$ demonstrates $\mathrm{UV}-\mathrm{V}$ is spectra of $\mathrm{Bi}_{2} \mathrm{WO}_{6}, \mathrm{Bi}_{2} \mathrm{~S}_{3}$, and $\mathrm{Bi}_{2} \mathrm{WO}_{6} / \mathrm{Bi}_{2} \mathrm{~S}_{3}$. The absorption band at about $440 \mathrm{~nm}$ showed the characteristic response of $\mathrm{Bi}_{2} \mathrm{WO}_{6}$ and the extended light absorption on the spectrum of $\mathrm{Bi}_{2} \mathrm{WO}_{6} /$ $\mathrm{Bi}_{2} \mathrm{~S}_{3}$ confirmed the synergistic effect between $\mathrm{Bi}_{2} \mathrm{WO}_{6}$ and $\mathrm{Bi}_{2} \mathrm{~S}_{3}$ [56]. 
Fig. 3 A SEM image of $\mathrm{g}-\mathrm{C}_{3} \mathrm{~N}_{4}$, TEM images of $\mathbf{B}$ and $\mathbf{C}$ g- $\mathrm{C}_{3} \mathrm{~N}_{4} / \mathrm{Au} / \mathrm{WO}_{3}$, D EDX image of $\mathrm{g}-\mathrm{C}_{3} \mathrm{~N}_{4} / \mathrm{Au} / \mathrm{WO}_{3}$, and $\mathbf{E}$ high-resolution TEM image of $\mathrm{g}-\mathrm{C}_{3} \mathrm{~N}_{4} / \mathrm{Au} / \mathrm{WO}_{3}$
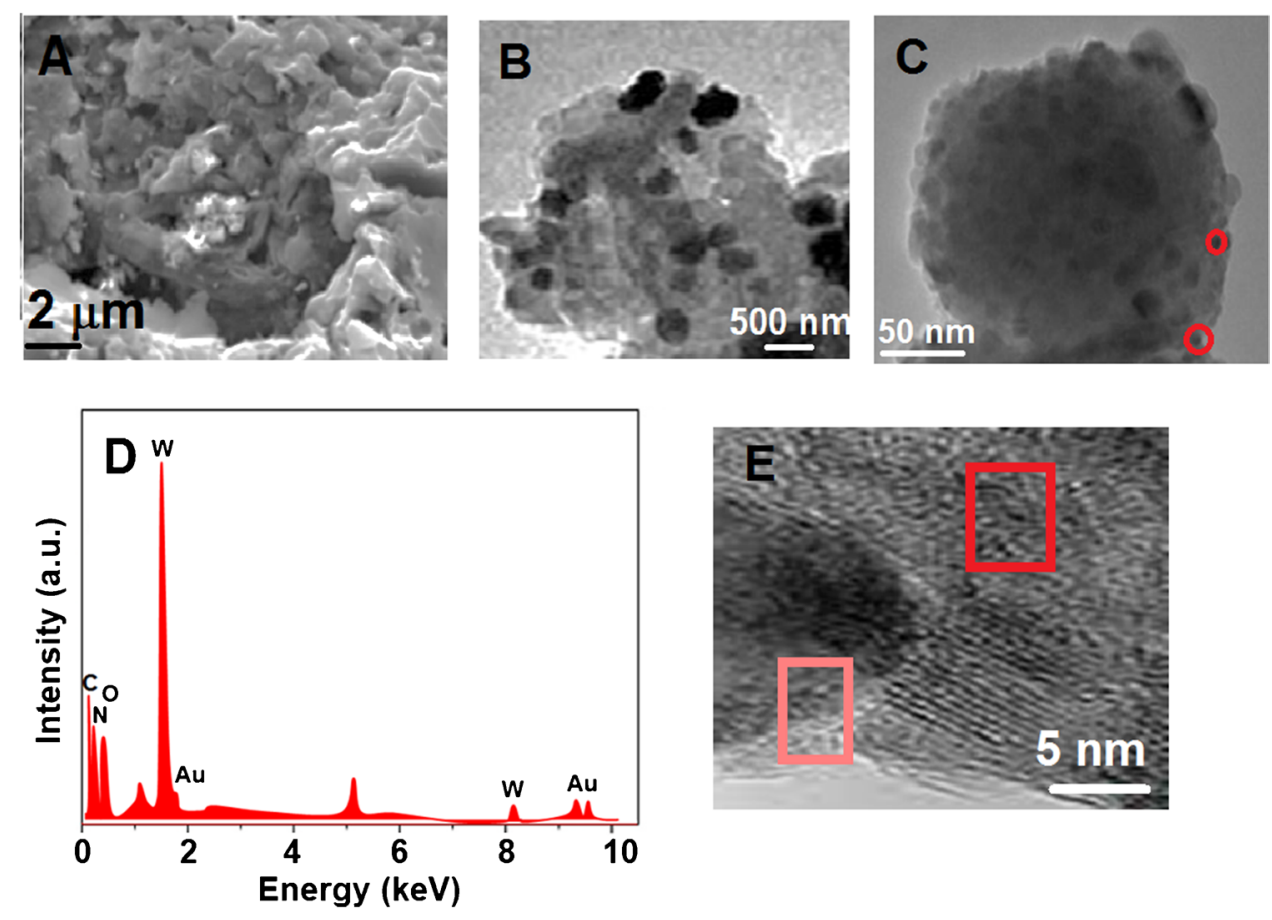

\section{Characterizations of g- $\mathrm{C}_{3} \mathrm{~N}_{4}, \mathrm{~g}-\mathrm{C}_{3} \mathrm{~N}_{4} / \mathrm{WO}_{3}$, and $\mathrm{g}-\mathrm{C}_{3} \mathrm{~N}_{4} / \mathrm{Au} / \mathrm{WO}_{3}$}

The crystalline structures and the surface morphologies of $\mathrm{g}-\mathrm{C}_{3} \mathrm{~N}_{4}, \mathrm{~g}-\mathrm{C}_{3} \mathrm{~N}_{4} / \mathrm{WO}_{3}$ and $\mathrm{g}-\mathrm{C}_{3} \mathrm{~N}_{4} / \mathrm{Au} / \mathrm{WO}_{3}$ were examined by TEM, SEM, XRD, and XPS techniques. The wrinkle structure of $\mathrm{g}-\mathrm{C}_{3} \mathrm{~N}_{4}$ was shown on Fig. $3 \mathrm{~A}$. According to Fig. 3B, it was revealed that $\mathrm{WO}_{3}$ spheres with a diameter of 280-320 nm were uniformly decorated on $\mathrm{g}_{-} \mathrm{C}_{3} \mathrm{~N}_{4}$ sheet, and AuNPs (red circle) with a small diameter placing between $\mathrm{g}-\mathrm{C}_{3} \mathrm{~N}_{4}$ and $\mathrm{WO}_{3}$ were deposited on $\mathrm{g}_{-} \mathrm{C}_{3} \mathrm{~N}_{4} / \mathrm{WO}_{3}$ sheet (Fig. 3C). Furthermore, an EDX image of g-C3N4/ $\mathrm{Au} / \mathrm{WO} 3$ revealed the existence of $\mathrm{C}, \mathrm{N}, \mathrm{O}, \mathrm{W}$, and Au elements, noting that the g-C3N4/Au/WO3 was successfully fabricated (Fig. 3D). Finally, high-resolution TEM image (Fig. 3E) of $\mathrm{g}-\mathrm{C}_{3} \mathrm{~N}_{4} / \mathrm{Au} / \mathrm{WO}_{3}$ demonstrated the lattice spacing of $\mathrm{Au} \mathrm{NP}$ (pink circle) and $\mathrm{WO}_{3}$ (red circle), indicating 0.272 and $0.212 \mathrm{~nm}$ which were attributed to $\mathrm{WO}_{3}(022)$ [57] and Au (200) [58].

The chemical states and the surface functionalities of g- $\mathrm{C}_{3} \mathrm{~N}_{4} / \mathrm{Au} / \mathrm{WO}_{3}$ were examined through XPS analysis (Fig. S2). According to Fig. S2A of the survey spectra, the peaks belonging to $\mathrm{C}, \mathrm{N}, \mathrm{O}, \mathrm{W}$, and Au elements confirmed the successful preparation of $\mathrm{g}-\mathrm{C}_{3} \mathrm{~N}_{4} / \mathrm{Au} / \mathrm{WO}_{3}$ in harmony with Fig. 3D [59]. The high-resolution C1s XRD spectra of sample deconvoluted into two main peaks at $285.1 \mathrm{eV}$ and $288.1 \mathrm{eV}$ corresponded to $\mathrm{C}-\mathrm{C}$ bond and $\mathrm{N}-\mathrm{C}$ groups (Fig. S2B) [60]. Moreover, N1s spectra (Fig. S2C) were deconvoluted into three main $\mathrm{N}$ configurations with the peaks detected at 398.1, 399.4, and $401.1 \mathrm{eV}$ attributing to $\mathrm{C}-\mathrm{N}-\mathrm{C},-\mathrm{N}=\mathrm{C}-$, and $\mathrm{N}-\mathrm{H}$, respectively [60]. The peak at $530.1 \mathrm{eV}$ attributing to lattice oxygen and the peak at $532.2 \mathrm{eV}$ corresponding to the chemisorbed oxygen species in $\mathrm{WO}_{3}$ were demonstrated on Fig. S2D [61]. Fig.S2E relating to $\mathrm{W} 4 \mathrm{f}$ shows that $\mathrm{W}$ $4 \mathrm{f} 7 / 2$ and $\mathrm{W} 4 \mathrm{f} 5 / 2$ of $\mathrm{W}^{6+}$ were located at 35.1 and $37.9 \mathrm{eV}$, respectively [62]. Finally, the peaks at 84.1 and $88.1 \mathrm{eV}$ were attributed to $\mathrm{Au} 4 \mathrm{f} 7 / 2$ and $4 \mathrm{f} 5 / 2$, respectively, indicating the existence of $\mathrm{Au}$ in composite material (Fig. S2F) [63].

The crystal structure of $\mathrm{g}-\mathrm{C}_{3} \mathrm{~N}_{4} / \mathrm{Au} / \mathrm{WO}_{3}$ composite was investigated by XRD (Fig. S3A). (002) crystal plane of $\mathrm{g}_{-} \mathrm{C}_{3} \mathrm{~N}_{4}$ was confirmed by the peak at $27.62^{\circ}$. After the preparation of $\mathrm{g}-\mathrm{C}_{3} \mathrm{~N}_{4} / \mathrm{Au}$ composite, a new XRD peak at $38.31^{\circ}$ was corresponded to Au NPs' (111) plane [64] and all peaks belonging to $\mathrm{WO}_{3}$ were attributed to the monoclinic phase of $\mathrm{WO}_{3}$ [65]. The observed peaks on XRD patterns of $g-\mathrm{C}_{3} \mathrm{~N}_{4} / \mathrm{WO}_{3}$ and $\mathrm{g}-\mathrm{C}_{3} \mathrm{~N}_{4} / \mathrm{Au} / \mathrm{WO}_{3}$ were similar to that of $\mathrm{WO}_{3}$. In addition, the peak at $27.62^{\circ}$ verified the presence of $\mathrm{g}-\mathrm{C}_{3} \mathrm{~N}_{4}$ and $\mathrm{WO}_{3}$. Nonetheless, the specific peaks of $\mathrm{Au}$ NPs were not observed on XRD pattern of $\mathrm{g}^{-} \mathrm{C}_{3} \mathrm{~N}_{4} / \mathrm{Au} / \mathrm{WO}_{3}$ composite, suggesting the low amount of Au NPs. UV-Vis spectra (Fig. S3B) were also recorded for g- $\mathrm{C}_{3} \mathrm{~N}_{4}, \mathrm{~g}-\mathrm{C}_{3} \mathrm{~N}_{4} /$ $\mathrm{WO}_{3}$, and $\mathrm{g}-\mathrm{C}_{3} \mathrm{~N}_{4} / \mathrm{Au} / \mathrm{WO}_{3}$. $\mathrm{g}-\mathrm{C}_{3} \mathrm{~N}_{4} / \mathrm{Au} / \mathrm{WO}_{3}$ composite having a wide absorption range effectively absorbs light, providing the increased catalytic response.

\section{Evaluation of the electrochemical characteristics of sensor platform and signal amplification}

Firstly, the electrochemical investigations for the prepared sensor platform were progressively performed by using $\mathrm{CV}$ 

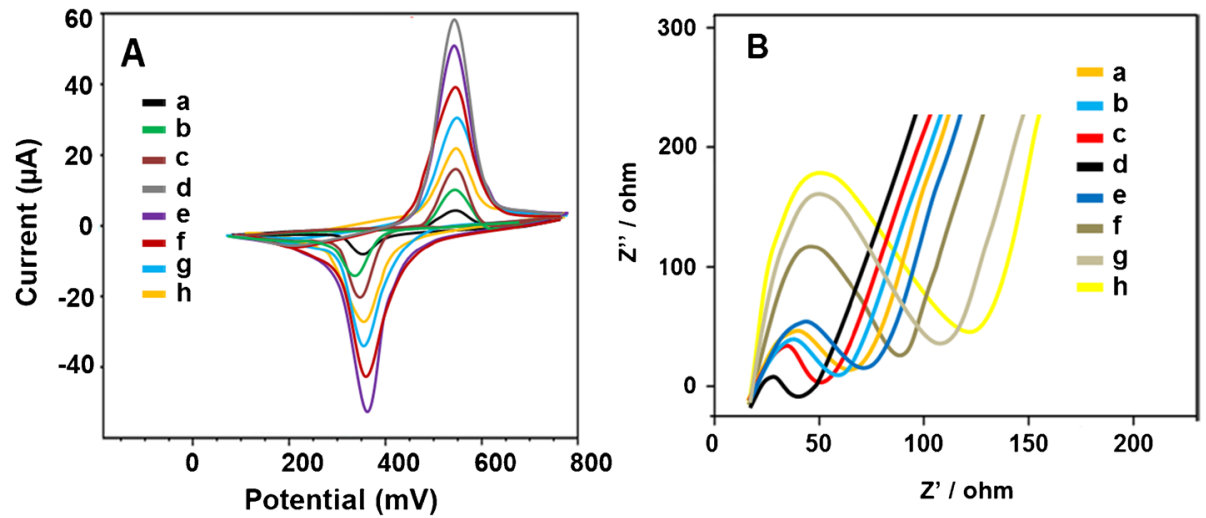

Fig. 4 A Cyclic voltammograms, B EIS reponses at (a) bare GCE, (b) $\mathrm{Bi}_{2} \mathrm{WO}_{6} / \mathrm{GCE}$, (c) $\mathrm{Bi}_{2} \mathrm{~S}_{3} / \mathrm{GCE}$, (d) $\mathrm{Bi}_{2} \mathrm{WO}_{6} / \mathrm{Bi}_{2} \mathrm{~S}_{3} / \mathrm{GCE}$, (e) c-SARS$\mathrm{CoV}-2-\mathrm{Ab}_{1} / \mathrm{Bi}_{2} \mathrm{WO}_{6} / \mathrm{Bi}_{2} \mathrm{~S}_{3} / \mathrm{GCE}$, (f) BSA/c-SARS-CoV-2-Ab $/$ $\mathrm{Bi}_{2} \mathrm{WO}_{6} / \mathrm{Bi}_{2} \mathrm{~S}_{3} / \mathrm{GCE}$, (g) SARS-CoV-2 NP/BSA/c-SARS-CoV-2-Ab 1 $\mathrm{Bi}_{2} \mathrm{WO}_{6} / \mathrm{Bi}_{2} \mathrm{~S}_{3} / \mathrm{GCE}$, (h) the final immunosensor including c-SARSCoV-2-Ab ${ }_{1}$, SARS-CoV-2 NP, and d-SARS-CoV-2-Ab 2 (scan rate

and EIS methods in presence of $1.0 \mathrm{mM}\left[\mathrm{Fe}(\mathrm{CN})_{6}\right]^{3-/ 4-}$ as redox pair. Firstly, the anodic and cathodic signals on bare GCE were observed at $E p a=550 \mathrm{mV}$ and $E p c=375 \mathrm{mV}$, respectively, (curve a of Fig. 4A). Due to the high stability and catalytic activity of $\mathrm{Bi}_{2} \mathrm{WO}_{6} / \mathrm{GCE}$ in the presence of $1.0 \mathrm{mM}\left[\mathrm{Fe}(\mathrm{CN})_{6}\right]^{3-/ 4-}$, more visible electrochemical signals were observed in contrast to bare glassy carbon electrode (curve $b$ of Fig. 4A) [32]. Then, there was more electrochemical catalytic effect on the signals (curve $\mathrm{c}$ of Fig. $4 \mathrm{~A}$ ) by using $\mathrm{Bi}_{2} \mathrm{~S}_{3} / \mathrm{GCE}$, indicated the narrow band gap $(1.3 \mathrm{eV})$ and the easy charge separation property [66]. Because $\mathrm{Bi}_{2} \mathrm{WO}_{6} / \mathrm{Bi}_{2} \mathrm{~S}_{3}$ composites improved catalytic activity and the improved electron separation and transfer, the highest electrochemical responses in comparison with $\mathrm{Bi}_{2} \mathrm{~S}_{3} / \mathrm{GCE}$ were obtained on $\mathrm{Bi}_{2} \mathrm{WO}_{6} / \mathrm{Bi}_{2} \mathrm{~S}_{3} / \mathrm{GCE}$ (curve $\mathrm{d}$ of Fig. 4A). Electroactive surface areas of the prepared electrode surfaces were calculated as $0.173 \pm 0.002 \mathrm{~cm}^{2}$ for bare GCE, $0.319 \pm 0.001 \mathrm{~cm}^{2}$ for $\mathrm{Bi}_{2} \mathrm{WO}_{6} / \mathrm{GCE}, 0.647 \pm 0.003$ $\mathrm{cm}^{2}$ for $\mathrm{Bi}_{2} \mathrm{~S}_{3} / \mathrm{GCE}$, and $1.113 \pm 0.006 \mathrm{~cm}^{2}$ for $\mathrm{Bi}_{2} \mathrm{WO}_{6} /$ $\mathrm{Bi}_{2} \mathrm{~S}_{3} / \mathrm{GCE}$ in the presence of $1.0 \mathrm{mM}\left[\mathrm{Fe}(\mathrm{CN})_{6}\right]^{3-}$ solution by $i_{p}=2.69 \times 10^{5} \mathrm{~A} \mathrm{n}^{3 / 2} \mathrm{D}^{1 / 2} \mathrm{C} \mathrm{v}^{1 / 2}$, where $i_{\mathrm{p}}$ was current, $C\left(\mathrm{~mol} \mathrm{~cm}{ }^{-3}\right)$ was $\left[\mathrm{Fe}(\mathrm{CN})_{6}\right]^{3-}$ concentration, $v$ was scan rate $\left(10-500 \mathrm{mV} \mathrm{s}^{-1}\right)$, and $A$ was surface area $\left(\mathrm{cm}^{2}\right)(n=1$, $D=7.6 \times 10^{-6} \mathrm{~cm}^{2} \mathrm{~s}^{-1}$ for $\left[\mathrm{Fe}(\mathrm{CN})_{6}\right]^{3-}$ ) [67]. Thus, $\mathrm{Bi}_{2} \mathrm{WO}_{6} /$ $\mathrm{Bi}_{2} \mathrm{~S}_{3}$ composite was chosen for future sensor platform.

As expected, the obvious electrochemical sensor signals decreased owing to c-SARS-CoV-2-A $b_{1}$ 's blocking effect on electron transfer (curve e of Fig. 4A). After the immobilizations of BSA (curve $\mathrm{f}$ of Fig. 4A) and SARS-CoV-2 NP (curve g of Fig. 4A), respectively, we observed that the sensor signals gradually decreased. Thus, it is concluded that the immobilization treatments of BSA and SARS-CoV-2 NP on electrode surface were successfully carried out. Finally, of $\left.50 \mathrm{mV} \mathrm{s}^{-1}\right)$ in $1.0 \mathrm{mM}\left[\mathrm{Fe}(\mathrm{CN})_{6}\right]^{3-}$ containing $0.1 \mathrm{M} \mathrm{KCl}$, and C DPV responses of the proposed immunosensors incubated with $0.2000 \mathrm{pg} \mathrm{mL}^{-1}$ SARS-CoV-2 NP using g- $\mathrm{C}_{3} \mathrm{~N}_{4} / \mathrm{WO}_{3} / \mathrm{d}-\mathrm{SARS}-\mathrm{CoV}-$ $2-\mathrm{Ab}_{2}$ (curve b) in presence of $1.0 \mathrm{mM} \mathrm{H} \mathrm{O}_{2}, \mathrm{~g}-\mathrm{C}_{3} \mathrm{~N}_{4} / \mathrm{Au} / \mathrm{WO}_{3} / \mathrm{d}$ SARS-CoV-2- $\mathrm{Ab}_{2}$ (curve c) in presence of $1.0 \mathrm{mM} \mathrm{H}_{2} \mathrm{O}_{2}$ and in absence of target analyte (curve a)

when the resulting immunosensor was used (curve $\mathrm{h}$ of Fig. 4A), further decrease on sensor signals was observed because of more antibody-nucleocapsid protein interactions.

Secondly, EIS experiments were performed to prove CV results and according to Fig. 4B, the obtained charge transfer resistances were calculated as 75.0, 65.0, 55.0, 40.0, 85.0, 95.0, 125.0, and $140.0 \Omega$ for bare GCE (curve a), $\mathrm{Bi}_{2} \mathrm{WO}_{6} l$ GCE (curve b), $\mathrm{Bi}_{2} \mathrm{~S}_{3} / \mathrm{GCE}$ (curve c), $\mathrm{Bi}_{2} \mathrm{WO}_{6} / \mathrm{Bi}_{2} \mathrm{~S}_{3} / \mathrm{GCE}$ (curve d), c-SARS-CoV-2- $\mathrm{Ab}_{1} / \mathrm{Bi}_{2} \mathrm{WO}_{6} / \mathrm{Bi}_{2} \mathrm{~S}_{3} / \mathrm{GCE}$ (curve e), BSA/c-SARS-CoV-2- $\mathrm{Ab}_{1} / \mathrm{Bi}_{2} \mathrm{WO}_{6} / \mathrm{Bi}_{2} \mathrm{~S}_{3} / \mathrm{GCE}$ (curve f), SARS-CoV-2 NP/BSA/c-SARS-CoV-2- $\mathrm{Ab}_{1} / \mathrm{Bi}_{2} \mathrm{WO}_{6} /$ $\mathrm{Bi}_{2} \mathrm{~S}_{3} / \mathrm{GCE}$ (curve $\mathrm{g}$ ), and the final immunosensor (curve h), respectively. Hence, the preparation procedure of immunosensor was completed successfully based on CV and EIS results.

For electrochemical performance characterization (Fig. 4C) of the prepared signal amplification, several immunosensors using g- $\mathrm{C}_{3} \mathrm{~N}_{4} / \mathrm{WO}_{3} / \mathrm{d}-\mathrm{SARS}-\mathrm{CoV}-2-\mathrm{Ab}_{2}$ (curve b) and $\mathrm{g}-\mathrm{C}_{3} \mathrm{~N}_{4} / \mathrm{Au} / \mathrm{WO}_{3} / \mathrm{d}-\mathrm{SARS}-\mathrm{CoV}-2-\mathrm{Ab}_{2}$ (curve c) were developed by using $0.2000 \mathrm{pg} \mathrm{mL}^{-1}$ SARS-CoV-2 NP at the immune reaction time of $30 \mathrm{~min}$ and DPV signals were observed in $1.0 \mathrm{mM} \mathrm{H}_{2} \mathrm{O}_{2}$. As expected, the highest electrochemical performance was obtained by the immunosensor based on $\mathrm{g}^{-} \mathrm{C}_{3} \mathrm{~N}_{4} / \mathrm{Au} / \mathrm{WO}_{3} / \mathrm{d}-\mathrm{SARS}-\mathrm{CoV}-2-\mathrm{Ab}_{2}$ in comparison with $\mathrm{g}^{-} \mathrm{C}_{3} \mathrm{~N}_{4} / \mathrm{WO}_{3} / \mathrm{d}-\mathrm{SARS}-\mathrm{CoV}-2-\mathrm{Ab}_{2}$. Because of the suppressing of electron transfer by $\mathrm{g}-\mathrm{C}_{3} \mathrm{~N}_{4} / \mathrm{WO}_{3}$ composite, a mediator such as AuNPs was needed at the interface for improving of electron transfer in Z-scheme heterojunction [59]. In addition, the stable electrochemical signals were observed by $\mathrm{g}-\mathrm{C}_{3} \mathrm{~N}_{4} / \mathrm{Au} / \mathrm{WO}_{3} / \mathrm{d}-\mathrm{SARS}-\mathrm{CoV}-2-\mathrm{Ab}_{2}$ owing to the strong covalent immobilization between $\mathrm{g}_{-} \mathrm{C}_{3} \mathrm{~N}_{4} / \mathrm{Au} /$ $\mathrm{WO}_{3}$ and d-SARS-CoV-2-Ab ${ }_{2}$. Curve a of Fig. $4 \mathrm{C}$ also demonstrated that there was no electrochemical signal in absence 
of target analyte. To verify the specific interaction between antibody-nucleocapsid protein, SEM image (Fig. S4) of the resulting immunosensor indicating a spherical size and agglomeration was obtained, providing a successful immune reaction.

\section{Optimization studies for electroanalytical characterizations}

The effects of the solution $\mathrm{pH}$, immune reaction time, $\mathrm{H}_{2} \mathrm{O}_{2}$, and $\mathrm{g}-\mathrm{C}_{3} \mathrm{~N}_{4} / \mathrm{Au} / \mathrm{WO}_{3} / \mathrm{d}-\mathrm{SARS}-\mathrm{CoV}-2-\mathrm{Ab}_{2}$ solution concentration were presented in detail (Fig. S5).

\section{Linearity range}

The obtained calibration equation by using SARSCoV-2 NP concentrations and the observed electrochemical immunosensor signals was calculated as $y=47.231 x+1.0666$, with a correlation coefficient of $R^{2}=0.9989$, where $y$ and $x$ represented the current $(\mu \mathrm{A})$ and SARS-CoV-2 NP concentration ( $\mathrm{pg} \mathrm{mL}^{-1}$ ), respectively (Fig. 5). The quantification limit (LOQ) and LOD were found to be $0.01 \mathrm{pg} \mathrm{mL}^{-1}$ and $3.00 \mathrm{fg} \mathrm{mL}^{-1}$, respectively. Equations (1) and (2) were employed to calculate LOQ and LOD:

$L O Q=10.0 \mathrm{~S} / \mathrm{m}$

$L O D=3.3 \mathrm{~S} / \mathrm{m}$

In addition, Table 1 shows some comparison features between the developed sandwich-type electrochemical SARS-CoV-2 NP and the other new detection methods. Firstly, the sensitive SARS-CoV-2 NP detection (LOD:
Fig. 5 Concentration effect (from 0.01 to $1.00 \mathrm{pg} \mathrm{mL}^{-1}$ SARS-CoV-2 NP) on immunosensor signals, Inset: calibration curve for electrochemical SARS-CoV-2 NP immunosensor (potential range is $+0.0 /+0.4 \mathrm{~V}$; Parameters are frequency of $100 \mathrm{~Hz}$, pulse amplitude of $25 \mathrm{mV}$, and scan increment of $5 \mathrm{mV}$ )
Table 1 The comparison of electrochemical SARS-CoV-2 NP immunosensor with the other novel techniques

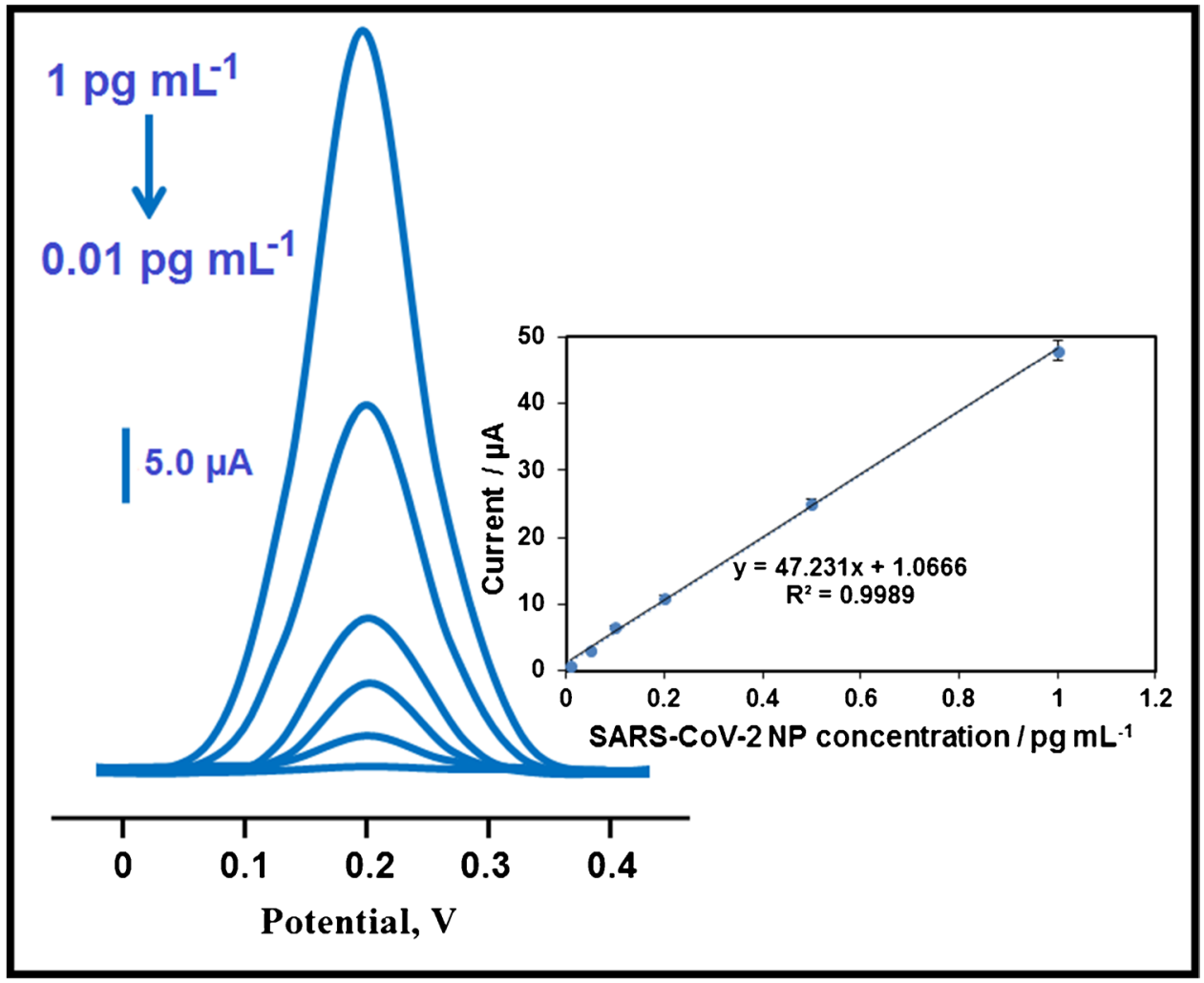

\begin{tabular}{|c|c|c|c|}
\hline Material/method & Linear range & Assay time & Ref \\
\hline Microfluidic & $0.0-10.0 \mathrm{ng} \mathrm{mL}^{-1} 50.0 \mathrm{pg} \mathrm{mL}^{-1}$ & $2 \mathrm{~min}$ & {$[68]$} \\
\hline Paper-based electrochemical & $1.0-1000.0 \mathrm{ng} \mathrm{mL}^{-1} 1.0 \mathrm{ng} \mathrm{mL}^{-1}$ & $30 \min$ & [7] \\
\hline Chemiluminescence & $0.2-100.0 \mathrm{ng} \mathrm{mL}^{-1} 0.1 \mathrm{ng} \mathrm{mL}^{-1}$ & $16 \min$ & [69] \\
\hline Electrochemical $/ \mathrm{Cu}_{2} \mathrm{O}$ nanocube & $0.25 \mathrm{fg} \mathrm{mL}^{-1}-1.00 \mu \mathrm{g} \mathrm{mL}^{-1} 0.04 \mathrm{fg} \mathrm{mL}^{-1}$ & $20 \mathrm{~min}$ & {$[70]$} \\
\hline $\mathrm{Ni}(\mathrm{OH})_{2} \mathrm{NPs}$ & $0.25 \mathrm{fg} \mathrm{mL}^{-1}-1.00 \mu \mathrm{g} \mathrm{mL}^{-1} 3.00 \mathrm{fg} \mathrm{mL}^{-1}$ & $20 \mathrm{~min}$ & [71] \\
\hline Electrochemical immunosensor & $0.01-1.00 \mathrm{pg} \mathrm{m} L^{-1} 3.00 \mathrm{fg} \mathrm{m}^{-1}$ & $30 \mathrm{~min}$ & This study \\
\hline
\end{tabular}


$3.00 \mathrm{fg} \mathrm{mL}^{-1}$ ) was performed in $30 \mathrm{~min}$ of immunological response time. More importantly, COVID-19 detection with high selectivity can be successfully performed from saliva samples by this immunosensor. In addition, thanks to the developed electrochemical SARS-CoV-2 NP immunosensor, the time-consuming steps in immunosensor development can be eliminated in this study. The preparation steps of $\mathrm{Bi}_{2} \mathrm{WO}_{6} / \mathrm{Bi}_{2} \mathrm{~S}_{3}$ electrode platform and $\mathrm{g}-\mathrm{C}_{3} \mathrm{~N}_{4} / \mathrm{Au} / \mathrm{WO}_{3}$ signal amplification comprised the minimal waste generation, indicating an immunosensor that is friendly to the environment and human health. As a result, the developed selective electrochemical SARS-CoV-2 NP immunosensor may offer a potential for early COVID-19 detection.

\section{Recovery}

The recovery experiments including saliva samples obtained from five healthy individuals were carried out by the portable electrochemical SARS-CoV-2 NP immunosensor. Table S1 indicates the close values to $100.00 \%$ confirming the preparation of high selective electrochemical SARS-CoV-2 NP immunosensor. Moreover, standard addition method was applied to saliva samples obtained from five healthy individuals and $y=47.249 x+10.171$, with $R^{2}=0.9994$, was obtained as calibration equation. Thus, the close slope values between direct calibration (inset of Fig. 5) and standard addition methods again verified the high selective COVID-19 detection.

The validity of the sandwich-type electrochemical immunosensor was evaluated by using colorimetric method [72]. Table S2 indicates the comparison results, showing that no significant difference was observed between the prepared immunosensor and colorimetric method ( $T_{\text {calculated }}>T_{\text {tabulated }}$, $p>0.05)$.

\section{Selectivity, stability, reproducibility, and reusability}

For selectivity measurement, the several electrochemical SARS-CoV-2 NP immunosensors were prepared by using different target dispersions such as (i) MERSCoV NP + SARS-CoV NP+H1N1, (ii) SARS-CoV-2 $\mathrm{NP}+$ MERS-CoV NP, (iii) SARS-CoV-2 NP+SARS-CoV $\mathrm{NP}$, (iv) SARS-CoV-2 NP+H1N1. Then, these electrochemical immunosensors were applied to $1.0 \mathrm{mM} \mathrm{H}_{2} \mathrm{O}_{2}$ solution. Figure $6 \mathrm{~A}$ confirms that the prepared electrochemical immunosensor demonstrated the high selectivity towards SARSCoV-2 nucleocapsid protein.

The stability test results of the constructed electrochemical SARS-CoV-2 NP immunosensor at $25.0^{\circ} \mathrm{C}$ for seven weeks were depicted in Fig. 6B. It was pointed out that the immunosensor signals were about $98.73 \%$ of the original electrochemical signal, indicating strong immunosensor stability.

Finally, for reproducibility, 10 different electrochemical SARS-CoV-2 NP immunosensors were developed by the protocol which is explained in the "Electrochemical characterizations" section. The relative standard deviation (RSD) of 0.61 was calculated by using the observed 10 electrochemical signals, confirming the high reliability of immunosensor production procedure.

Reusability of prepared electrochemical SARS-CoV-2 NP immunosensor was tested in $1.0 \mathrm{mM} \mathrm{H}_{2} \mathrm{O}_{2}$ solution. One
Fig. 6 A Immunosensor selective responses against the prepared solutions $(n=6)$ : (i) $10.0 \mathrm{pg} \mathrm{mL}^{-1}$ MERS-CoV $\mathrm{NP}+10.0 \mathrm{pg} \mathrm{mL}^{-1}$ SARS-CoV $\mathrm{NP}+10.0 \mathrm{pg} \mathrm{mL}^{-1} \mathrm{H} 1 \mathrm{~N} 1$, (ii) $0.2000 \mathrm{pg} \mathrm{mL}^{-1}$ SARS-CoV-2 $\mathrm{NP}+10.0 \mathrm{pg} \mathrm{mL}^{-1} \mathrm{MERS}-\mathrm{CoV}$ $\mathrm{NP}$, (iii) $0.2000 \mathrm{pg} \mathrm{mL}^{-1} \mathrm{SARS}$ CoV-2 NP+10.0 $\mathrm{pg} \mathrm{mL}^{-1}$ SARS-CoV NP, (iv) $0.2000 \mathrm{pg} \mathrm{mL}^{-1}$ SARS-CoV-2 $\mathrm{NP}+10.0 \mathrm{pg} \mathrm{mL}^{-1} \mathrm{H} 1 \mathrm{~N} 1 ; \mathbf{B}$ Stability test of electrochemical SARS-CoV-2 NP immunosensor including $0.2000 \mathrm{pg} \mathrm{mL}^{-1}$ SARS-CoV-2 NP $(n=6)$ at $25.0{ }^{\circ} \mathrm{C}$
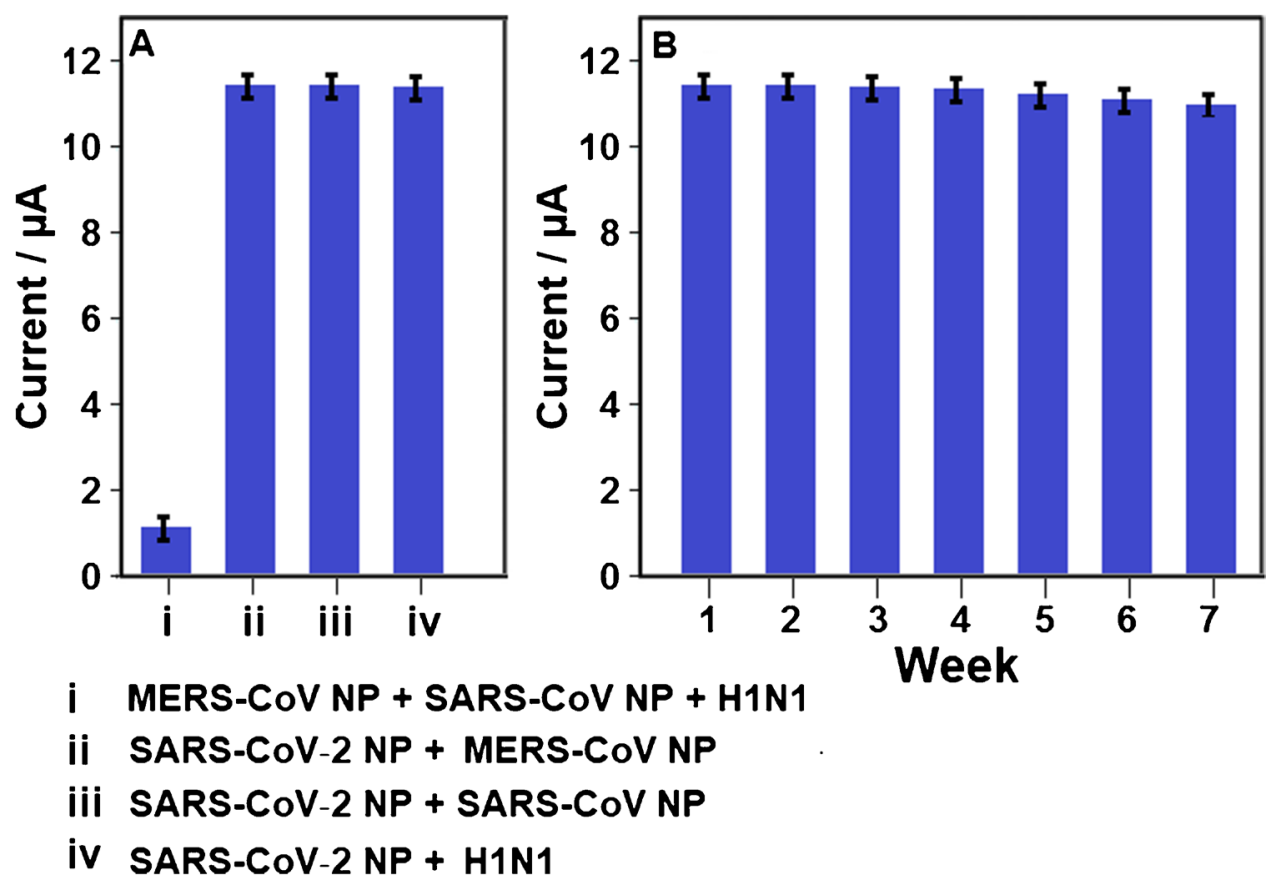

ii SARS-CoV-2 NP + MERS-CoV NP

iv SARS-COV-2 NP + H1N1 
SARS-CoV-2 NP immunosensor was utilized at least 30 times and $0.89 \%$ of RSD was obtained for current signals, confirming high reusability of prepared electrochemical SARS-CoV-2 NP immunosensor in this study.

\section{Precision and accuracy}

The studies of same day (intra-day precision) and six consecutive days (inter-day precision) were carried out in presence of three concentrations $\left(0.3000,0.5000\right.$, and $0.7000 \mathrm{pg} \mathrm{mL}^{-1}$ SARS-CoV-2 NP) in linearity range (Table S3). The values of RSD for intra-day and inter-day precision were obtained as $0.070-0.098$ and $0.035-0.098$, respectively. Hence, low RSD verified high precision of prepared electrochemical SARS-CoV-2 NP immunosensor. Accuracy as Bias $\%$ was also tested and low Bias \% (Table S3) suggested the high accuracy of electrochemical SARS-CoV-2 NP immunosensor.

\section{Conclusions}

COVID-19 pandemic has caused important damage to society. Until now, many kits for SARS-CoV-2 sensing have been developed. For first time, sensitive electrochemical SARS-CoV-2 nucleocapsid protein immunosensor based on $\mathrm{Bi}_{2} \mathrm{WO}_{6} / \mathrm{Bi}_{2} \mathrm{~S}_{3}$ as electrode platform and $\mathrm{g}^{-\mathrm{C}_{3}} \mathrm{~N}_{4} / \mathrm{Au} /$ $\mathrm{WO}_{3}$ as signal amplification was presented in this work. This immunosensor was constructed by c-SARS-CoV$2-\mathrm{Ab}_{1}$ immobilization via strong electrostatic interaction and d-SARS-CoV-2-Ab $\mathrm{b}_{2}$ incubation via gold-amino affinity. Thus, the stable electrochemical signals were accomplished in terms of COVID-19 disease detection. In addition, the prepared electrochemical immunosensor had good ability in selective detection of SARS-CoV-2 nucleocapsid protein. In spite of these advantages, the presented detection protocol was a little time consuming in immunological response time (30 $\mathrm{min}$ ), indicating that this analysis time is significant in terms of faster diagnosis. Furthermore, the prepared immunosensor based on $\mathrm{Bi}_{2} \mathrm{WO}_{6} / \mathrm{Bi}_{2} \mathrm{~S}_{3}$ and $\mathrm{g}^{-} \mathrm{C}_{3} \mathrm{~N}_{4} / \mathrm{Au} / \mathrm{WO}_{3}$ was reproducible and reusable biosensor and did not include in time-consuming steps such as sensor preparation. Finally, this developed immunosensor can be easily integrated into a commercial biosensor tool and used for the determination of the other viral diseases.

Supplementary Information The online version contains supplementary material available at https://doi.org/10.1007/s00604-021-05092-6.

Acknowledgements Mehmet Lütfi YOLA would like to express his gratitude to the Turkish Academy of Sciences for their precious support in respect to The Young Scientists Award Programme, TÜBA-GEBIP (2019).

\section{Declarations}

Conflict of interest The authors declare no competing interests.

\section{References}

1. Seo G, Lee G, Kim MJ, Baek SH, Choi M, Ku KB, Lee CS, Jun S, Park D, Kim HG, Kim SJ, Lee JO, Kim BT, Park EC, Kim SI (2020) Correction to rapid detection of COVID-19 causative virus (SARS-CoV-2) in human nasopharyngeal swab specimens using field-effect transistor-based biosensor. ACS Nano 14(9):12257-12258

2. Fauci AS, Lane HC, Redfield RR (2020) Covid-19 - navigating the uncharted. N Engl J Med 382(13):1268-1269

3. Nguyen TT, Le XTT, Nguyen NTT, Nguyen QN, Le HT, Pham QT, Ta NKT, Nguyen QT, Nguyen AN, Hoang MT, Pham HQ, Vu LG, Luong AM, Koh D, Nguyen TH, Tran BX, Latkin CA, Ho CSH, Ho RCM (2021) Psychosocial impacts of COVID-19 on healthcare workers during the nationwide partial lockdown in Vietnam in April 2020. Front Psychiatry. 12:562337

4. Morales-Narvaez E, Dincer C (2020) The impact of biosensing in a pandemic outbreak: COVID-19. Biosens Bioelectron. 163:112274

5. Pokhrel P, Hu C, Mao H (2020) Detecting the Coronavirus (COVID-19). ACS Sens 5(8):2283-2296

6. Udugama B, Kadhiresan P, Kozlowski HN, Malekjahani A, Osborne M, Li VYC, Chen H, Mubareka S, Gubbay JB, Chan WCW (2020) Diagnosing COVID-19: the disease and tools for detection. ACS Nano 14(4):3822-3835

7. Yakoh A, Pimpitak U, Rengpipat S, Hirankarn N, Chailapakul O, Chaiyo S (2021) Paper-based electrochemical biosensor for diagnosing COVID-19: detection of SARS-CoV-2 antibodies and antigen. Biosens Bioelectron. 176:112912

8. Zhang W, Du RH, Li B, Zheng XS, Yang XL, Hu B, Wang YY, Xiao GF, Yan B, Shi ZL, Zhou P (2020) Molecular and serological investigation of 2019-nCoV infected patients: implication of multiple shedding routes. Emerg Microbes Infect 9(1):386-389

9. Fang Y, Zhang H, Xie J, Lin M, Ying L, Pang P, Ji W (2020) Sensitivity of Chest CT for COVID-19: comparison to RT-PCR. Radiology 296(2):E115-E117

10. Wolfel R, Corman VM, Guggemos W, Seilmaier M, Zange S, Muller MA, Niemeyer D, Jones TC, Vollmar P, Rothe C, Hoelscher M, Bleicker T, Brunink S, Schneider J, Ehmann R, Zwirglmaier K, Drosten C, Wendtner C (2020) Virological assessment of hospitalized patients with COVID-2019. Nature 581(7809):465-469

11. Polat C, Karaman O, Karaman C, Korkmaz G, Balci MC, Kelek SE (2021) COVID-19 diagnosis from chest X-ray images using transfer learning: enhanced performance by debiasing dataloader. J Xray Sci Technol 29(1):19-36

12. Alhudhaif A, Polat K, Karaman O (2021) Determination of COVID-19 pneumonia based on generalized convolutional neural network model from chest X-ray images. Expert Syst Appl. 180:115141

13. Song Z, Ma Y, Chen M, Ambrosi A, Ding C, Luo X (2021) Electrochemical biosensor with enhanced antifouling capability for COVID-19 nucleic acid detection in complex biological media. Anal Chem 93(14):5963-5971

14. Xiao SY, Wu Y, Liu H (2020) Evolving status of the 2019 novel coronavirus infection: proposal of conventional serologic assays for disease diagnosis and infection monitoring. J Med Virol 92(5):464-467

15. Guo L, Ren L, Yang S, Xiao M, Chang YF, Dela Cruz CS, Wang Y, Wu C, Xiao Y, Zhang L, Han L, Dang S, Xu Y, Yang QW, Xu 
SY, Zhu HD, Xu YC, Jin Q, Sharma L, Wang L, Wang J (2020) Profiling early humoral response to diagnose novel coronavirus disease (COVID-19). Clin Infect Dis 71(15):778-785

16. Liu W, Liu L, Kou G, Zheng Y, Ding Y, Ni W, Wang Q, Tan L, Wu W, Tang S, Xiong Z, Zheng S (2020) Evaluation of nucleocapsid and spike protein-based enzyme-linked immunosorbent assays for detecting antibodies against SARS-CoV-2. J Clin Microbiol 58(6): e00461-e420

17. Zhao J, Yuan Q, Wang H, Liu W, Liao X, Su Y, Wang X, Yuan J, Li T, Li J, Qian S, Hong C, Wang F, Liu Y, Wang Z, He Q, Li Z, He B, Zhang T, Fu Y, Ge S, Liu L, Zhang J, Xia N, Zhang Z (2020) Antibody responses to SARS-CoV-2 in patients with novel coronavirus disease 2019. Clin Infect Dis 71(16):2027-2034

18. Li Z, Yi Y, Luo X, Xiong N, Liu Y, Li S, Sun R, Wang Y, Hu B, Chen W, Zhang Y, Wang J, Huang B, Lin Y, Yang J, Cai W, Wang X, Cheng J, Chen Z, Sun K, Pan W, Zhan Z, Chen L, Ye F (2020) Development and clinical application of a rapid IgM-IgG combined antibody test for SARS-CoV-2 infection diagnosis. J Med Virol 92(9):1518-1524

19. Liu X, Wang J, Xu X, Liao G, Chen Y, Hu CH (2020) Patterns of IgG and IgM antibody response in COVID-19 patients. Emerg Microbes Infect 9(1):1269-1274

20. Chen Z, Zhang Z, Zhai X, Li Y, Lin L, Zhao H, Bian L, Li P, Yu L, Wu Y, Lin G (2020) Rapid and sensitive detection of anti-SARSCoV-2 IgG, using lanthanide-doped nanoparticles-based lateral flow immunoassay. Anal Chem 92(10):7226-7231

21. Eissa S, Zourob M (2021) Development of a low-cost cottontipped electrochemical immunosensor for the detection of SARSCoV-2. Anal Chem 93(3):1826-1833

22. Caygill RL, Blair GE, Millner PA (2010) A review on viral biosensors to detect human pathogens. Anal Chim Acta 681(1-2):8-15

23. Khan MZH, Hasan MR, Hossain SI, Ahommed MS, Daizy M (2020) Ultrasensitive detection of pathogenic viruses with electrochemical biosensor: state of the art. Biosens Bioelectron. 166:112431

24. Samson R, Navale GR, Dharne MS (2020) Biosensors: frontiers in rapid detection of COVID-19. 3 Biotech. 10(9):385

25. Wang G, Han R, Li Q, Han Y, Luo X (2020) Electrochemical biosensors capable of detecting biomarkers in human serum with unique long-term antifouling abilities based on designed multifunctional peptides. Anal Chem 92(10):7186-7193

26. Xu X, Liu Z, Zuo Z, Zhang M, Zhao Z, Shen Y, Zhou H, Chen Q, Yang Y, Wang M (2015) Hole selective NiO contact for efficient perovskite solar cells with carbon electrode. Nano Lett 15(4):2402-2408

27. Scholes GD (2011) Semiconductor nanostructures: two dimensions are brighter. Nat Mater 10(12):906-907

28. Yu Z, Tetard L, Zhai L, Thomas J (2015) Supercapacitor electrode materials: nanostructures from 0 to 3 dimensions. Energy \& Environmental Science. 8:702-730

29. Meng X, Zhang Z (2017) Pd-doped Bi2MoO6 plasmonic photocatalysts with enhanced visible light photocatalytic performance. Appl Surf Sci 392:169-180

30. Li N, Sun YA, Wang FY, Huang CA, Fu CP, Zhang LN, Liu YQ, Ge SG, Yu JH (2021) Target dual-recycling-induced bipedal DNA walker and Bi2WO6/Bi2S3 cascade amplification strategy in photoelectrochemical biosensor for TP53 detection. Sensor Actuat B-Chem. 345:130386

31. Lv SZ, Zhang KY, Zeng YY, Tang DP (2018) Double photosystems-based "Z-scheme" photoelectrochemical sensing mode for ultrasensitive detection of disease biomarker accompanying three-dimensional DNA walker. Anal Chem 90(11):7086-7093

32. Li C, Chen G, Sun J, Rao J, Han Z, Hu Y, Zhou Y (2015) A novel mesoporous single-crystal-like Bi2WO6 with enhanced photocatalytic activity for pollutants degradation and oxygen production. ACS Appl Mater Interfaces 7(46):25716-25724
33. Yan L, Wang Y, Shen H, Zhang Y, Li J, Wang D (2017) Photocatalytic activity of Bi2WO6/Bi2S3 heterojunctions: the facilitation of exposed facets of Bi2WO6 substrate. Appl Surf Sci 393:496-503

34. Li WT, Huang WZ, Zhou H, Yin HY, Zheng YF, Song XC (2015) Synthesis and photoactivity enhancement of Ba doped Bi2WO6 photocatalyst. Mater Res Bull 64:432-437

35. Li M, Zhang L, Fan X, Zhou Y, Wu M, Shi J (2015) Highly selective CO 2 photoreduction to CO over gC 3 N 4/Bi 2 WO 6 composites under visible light. Journal of Materials Chemistry A 39(9):5189-5196

36. Zhang B, Tang Y, Wu X, Xie H, Zhao F, Zeng B (2021) Experimental and DFT studies of novel Z-scheme Bi-doped Bi2WO6/ $\mathrm{Bi} 2 \mathrm{~S} 3 \mathrm{pn} / \mathrm{n}$ homo/heterojunction and its application in cathodic photoelectrochemical immunosensing. Sensors and Actuators B: Chemical. 346:130455

37. Raizada P, Sudhaik A, Singh P, Hosseini-Bandegharaei A, Thakur P (2019) Converting type II AgBr/VO into ternary Z scheme photocatalyst via coupling with phosphorus doped g-C3N4 for enhanced photocatalytic activity. Separation and Purification Technology. 227:115692

38. Karaman C, Karaman O, Atar N, Yola ML (2021) Electrochemical immunosensor development based on core-shell high-crystalline graphitic carbon nitride@ carbon dots and Cd0.5Zn0.5S/dTi3C2Tx MXene composite for heart-type fatty acid-binding protein detection. Microchimica Acta. 188(6): 182.

39. Meng J, Wang X, Liu Y, Ren M, Zhang X, Ding X, Guo Y, Yang Y (2021) Acid-induced molecule self-assembly synthesis of $\mathrm{Z}$-scheme WO3/g-C3N4 heterojunctions for robust photocatalysis against phenolic pollutants. Chemical Engineering Journal. 403:126354

40. Xue JW, Yang L, Wang H, Yan T, Fan DW, Feng R, Du B, Wei Q, Ju HX (2019) Quench-type electrochemiluminescence immunosensor for detection of amyloid beta-protein based on resonance energy transfer from luminol@SnS2-Pd to Cu doped WO3 nanoparticles. Biosens Bioelectron 133:192-198

41. Zhang YX, Cao XY, Deng RX, Liu QY, Xia JF, Wang ZH (2019) DNA synergistic enzyme-mediated cascade reaction for homogeneous electrochemical bioassay. Biosensors \& Bioelectronics. 142:111510

42. Yola ML, Atar N, Qureshi MS, Üstündağ Z, Solak AO (2012) Electrochemically grafted etodolac film on glassy carbon for $\mathrm{Pb}$ (II) determination. Sens Actuators, B Chem 171:1207-1215

43. Yola ML (2021) Sensitive sandwich-type voltammetric immunosensor for breast cancer biomarker HER2 detection based on gold nanoparticles decorated $\mathrm{Cu}-\mathrm{MOF}$ and $\mathrm{Cu} 2 \mathrm{ZnSnS} 4 \mathrm{NPs} / \mathrm{Pt} / \mathrm{g}$ C3N4 composite. Mikrochim Acta 188(3):78

44. Jie X, Zeng D, Zhang J, Xu K, Wu J, Zhu B, Xie C (2015) Graphene-wrapped WO3 nanospheres with room-temperature NO2 sensing induced by interface charge transfer. Sens Actuators, B Chem 220:201-209

45. Glisic BD, Rychlewska U, Djuran MI (2012) Reactions and structural characterization of gold(III) complexes with amino acids, peptides and proteins. Dalton Trans 41(23):6887-6901

46. La Belle JT, Demirok UK, Patel DR, Cook CB (2011) Development of a novel single sensor multiplexed marker assay. Analyst 136(7):1496-1501

47. Zhou Y, Zhang Y, Lin M, Long J, Zhang Z, Lin H, Wu JC, Wang X (2015) Monolayered Bi2WO6 nanosheets mimicking heterojunction interface with open surfaces for photocatalysis. Nat Commun 6:8340

48. Mahato K, Purohit B, Bhardwaj K, Jaiswal A, Chandra P (2019) Novel electrochemical biosensor for serotonin detection based on gold nanorattles decorated reduced graphene oxide in biological fluids and in vitro model. Biosens Bioelectron. 142:111502

49. Yola ML, Atar N (2020) Amperometric galectin-3 immunosensorbased gold nanoparticle-functionalized graphitic carbon nitride 
nanosheets and core-shell Ti-MOF@COFs composites. Nanoscale 12(38):19824-19832

50. Medetalibeyoglu H, Beytur M, Akyıldırım O, Atar N, Yola ML (2020) Validated electrochemical immunosensor for ultra-sensitive procalcitonin detection: carbon electrode modified with gold nanoparticles functionalized sulfur doped MXene as sensor platform and carboxylated graphitic carbon nitride as signal amplification. Sensors and Actuators B: Chemical. 319:128195

51. Wang H, Jian Y, Kong Q, Liu H, Lan F, Liang L, Ge S, Yu J (2018) Ultrasensitive electrochemical paper-based biosensor for microRNA via strand displacement reaction and metal-organic frameworks. Sens Actuators, B Chem 257:561-569

52. Chen J, Luo Z, Sun C, Huang Z, Zhou C, Yin S, Duan Y, Li Y (2019) Research progress of DNA walker and its recent applications in biosensor. TrAC Trends in Analytical Chemistry 120:115626

53. Li W, Ding X, Wu H, Yang H (2018) In-situ hydrothermal synthesis of TiO2/Bi2WO6 heterojunction with enhanced photocatalytic activity. Mater Lett 227:272-275

54. Tang QY, Chen WF, Lv YR, Yang SY, Xu YH (2020) Z-scheme hierarchical $\mathrm{Cu} 2 \mathrm{~S} / \mathrm{Bi} 2 \mathrm{WO} 6$ composites for improved photocatalytic activity of glyphosate degradation under visible light irradiation. Separation and Purification Technology. 236:116243

55. Zhang P, Cui Y, Yao Y, Wei W, Sun Y, Zhang K, Gao Y (2021) "Bi-O" vacancy-pairs induced photochromic behavior in Bi2WO6 ultrathin nanosheets. Solar Energy Materials and Solar Cells. 223:110988

56. Li N, Sun Y, Wang F, Huang C, Fu C, Zhang L, Liu Y, Ge S, Yu J (2021) Target dual-recycling-induced bipedal DNA walker and Bi2WO6/Bi2S3 cascade amplification strategy in photoelectrochemical biosensor for TP53 detection. Sensors and Actuators B: Chemical. 345:130386

57. Batool S, Idrees M, Javed MS, Saleem M, Kong J (2020) Engaging tailored capacity of layered WS2 via sulphur bonding coupled with polyetherimide (WS2@NC) nanocomposite for high power and improved lithium-ion storage. Materials Chemistry and Physics. 246:122832

58. Hsueh TJ, Wu SS (2021) Highly sensitive Co3O4 nanoparticles/ MEMS NO2 gas sensor with the adsorption of the Au nanoparticles. Sensors and Actuators B: Chemical. 329:129201

59. Pei F, Feng S, Wu Y, Lv X, Wang H, Chen SM, Hao Q, Cao Y, Lei W, Tong Z (2021) Label-free photoelectrochemical immunosensor for aflatoxin $\mathrm{B} 1$ detection based on the Z-scheme heterojunction of g-C3N4/Au/WO3. Biosens Bioelectron. 189:113373

60. Karaman C, Karaman O, Atar N, Yola ML (2021) Sustainable electrode material for high-energy supercapacitor: biomassderived graphene-like porous carbon with three-dimensional hierarchically ordered ion highways. Phys Chem Chem Phys 23(22):12807-12821

61. Lei J, Liu H, Yuan C, Chen Q, Liu JA, Wen F, Jiang X, Deng W, Cui X, Duan T, Zhu W (2021) Enhanced photoreduction of U (VI) on WO3 nanosheets by oxygen defect engineering. Chemical Engineering Journal. 416:129164
62. Liu X, Jin A, Jia Y, Xia T, Deng C, Zhu M, Chen C, Chen X (2017) Synergy of adsorption and visible-light photocatalytic degradation of methylene blue by a bifunctional Z-scheme heterojunction of WO3/g-C3N4. Appl Surf Sci 405:359-371

63. Zhao W, Dong Q, Sun C, Xia D, Huang H, Yang G, Wang G, Leung DY (2021) A novel Au/g-C3N4 nanosheets/CeO2 hollow nanospheres plasmonic heterojunction photocatalysts for the photocatalytic reduction of hexavalent chromium and oxidation of oxytetracycline hydrochloride. Chemical Engineering Journal. 409:128185

64. Chen L, Zeng X, Si P, Chen Y, Chi Y, Kim DH, Chen G (2014) Gold nanoparticle-graphite-like C3N4 nanosheet nanohybrids used for electrochemiluminescent immunosensor. 86: 4188-4195.

65. Yoon M, Oh Y, Hong S, Lee JS, Boppella R, Kim SH, Mota FM, Kim SO, Kim DH (2017) Synergistically enhanced photocatalytic activity of graphitic carbon nitride and WO3 nanohybrids mediated by photo-Fenton reaction and $\mathrm{H} 2 \mathrm{O} 2$. Appl Catal B 206:263-270

66. Sarkar A, Ghosh AB, Saha N, Dutta AK, Srivastava DN, Paul P, Adhikary B (2015) Enhanced photocatalytic activity of Eu-doped Bi 2 S 3 nanoflowers for degradation of organic pollutants under visible light illumination. Catal Sci Technol 5(8):4055-4063

67. Yola ML (2021) Sensitive sandwich-type voltammetric immunosensor for breast cancer biomarker HER2 detection based on gold nanoparticles decorated $\mathrm{Cu}-\mathrm{MOF}$ and $\mathrm{Cu} 2 \mathrm{ZnSnS} 4 \mathrm{NPs} / \mathrm{Pt} / \mathrm{g}-$ C3N4 composite. Microchim Acta 188(3):78

68. Li J, Lillehoj PB (2021) Microfluidic magneto immunosensor for rapid, high sensitivity measurements of SARS-CoV-2 nucleocapsid protein in serum. ACS Sens 6(3):1270-1278

69. Liu D, Ju C, Han C, Shi R, Chen X, Duan D, Yan J, Yan X (2020) Nanozyme chemiluminescence paper test for rapid and sensitive detection of SARS-CoV-2 antigen. Biosens Bioelectron. 173:112817

70. Rahmati Z, Roushani M, Hosseini H, Choobin H (2021) Electrochemical immunosensor with $\mathrm{Cu} 2 \mathrm{O}$ nanocube coating for detection of SARS-CoV-2 spike protein. Mikrochim Acta 188(3):105

71. Rahmati Z, Roushani M, Hosseini H, Choobin H (2021) An electrochemical immunosensor using SARS-CoV-2 spike proteinnickel hydroxide nanoparticles bio-conjugate modified SPCE for ultrasensitive detection of SARS-CoV-2 antibodies. Microchem J. 170:106718

72. Karakus E, Erdemir E, Demirbilek N, Liv L (2021) Colorimetric and electrochemical detection of SARS-CoV-2 spike antigen with a gold nanoparticle-based biosensor. Analytica Chimica Acta. 1182:338939

Publisher's note Springer Nature remains neutral with regard to jurisdictional claims in published maps and institutional affiliations. 